\title{
IMPACT EVALUATION OF THE DFID PROGRAMME TO ACCELERATE IMPROVED NUTRITION FOR EXTREME POOR IN BANGLADESH
}

INTERIM REPORT OF THE FINDINGS FROM THE QUANTITATIVE BASELINE AND THE QUALITATIVE FIELDWORK

\section{MQSUN REPORT}

Authors:

Barnett I., Jahan F., Siddiki O. F., Roy S., Longhurst R., Nisbett N. , Trachant J.P., Gordon J., Naher, F., Ahmed, F. and Islam, A.

June 2015 


\section{ABOUT MQSUN}

MQSUN aims to provide the Department for International Development (DFID) with technical services to improve the quality of nutrition-specific and nutrition-sensitive programmes. The project is resourced by a consortium of six leading non-state organisations working on nutrition. The consortium is led by PATH.

The group is committed to:

- $\quad$ Expanding the evidence base on the causes of undernutrition

- Enhancing skills and capacity to support scaling up of nutrition-specific and nutrition-sensitive programmes

- $\quad$ Providing the best guidance available to support programme design, implementation, monitoring and evaluation

- Increasing innovation in nutrition programmes

- Knowledge-sharing to ensure lessons are learnt across DFID and beyond.

\subsection{MQSUN partners are:}

Aga Khan University

Agribusiness Systems International

ICF International

Institute for Development Studies

Health Partners International, Inc.

PATH

\subsection{Contact}

PATH, 455 Massachusetts Avenue NW, Suite 1000

Washington, DC 20001 USA

Tel: (202) 822-0033

Fax: (202) 457-1466

\subsection{About this publication}

This Mixed Methods Report was produced by The Institute for Development Studies (IDS) through the UK Government's Department for International Development (DFID)-funded MQSUN project, "Impact Evaluation of the DFID Programme to Accelerate Improved Nutrition for the Extreme Poor in Bangladesh".

This document was produced through support provided by UKAid from the Department for International Development, including via the Transform Nutrition Research Programme Consortium. The opinions herein are those of the authors and do not necessarily reflect the views of the Department for International Development. 


\section{CONTENTS}

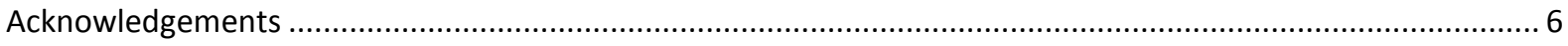

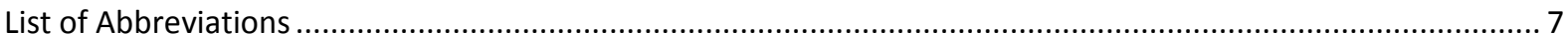

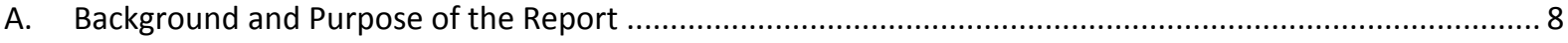

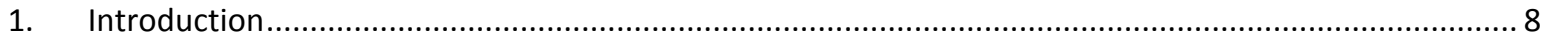

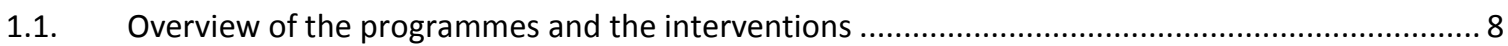

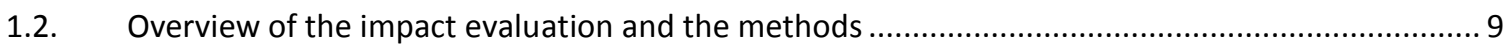

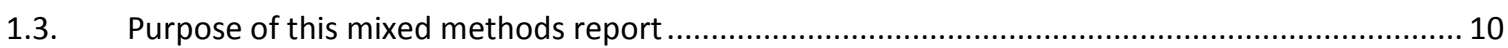

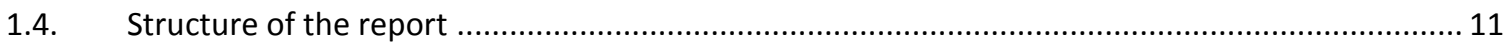

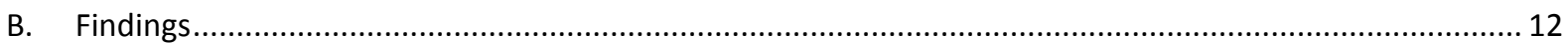

2. Features, benefits and challenges of the three livelihood programmes ........................................... 12

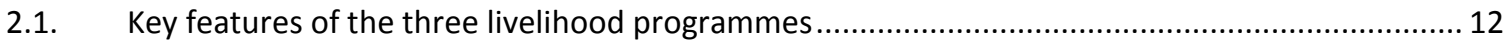

2.2. Beneficiaries experiences with the livelihood programmes .................................................. 14

2.3. Perceptions of why the livelihood intervention did not result in an improvement in nutrition in

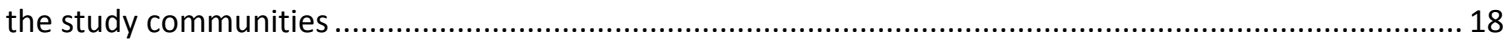

2.4. Summary matrix of quantitative and qualitative findings on the three livelihood programmes ... 18

3. The nature of child undernutrition and its potential reasons across the 3 programme sites ................20

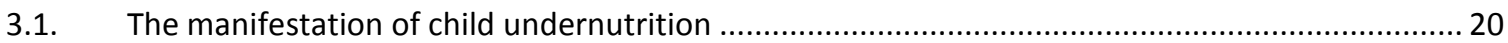

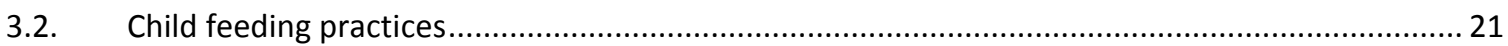

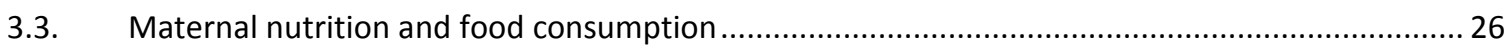

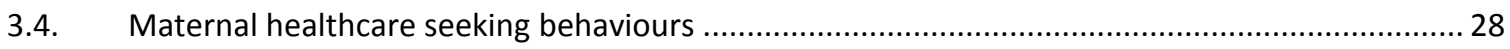

3.5. Summary matrix of quantitative and qualitative key findings on nutrition................................ 30

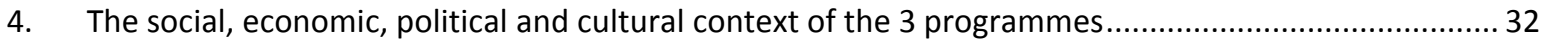

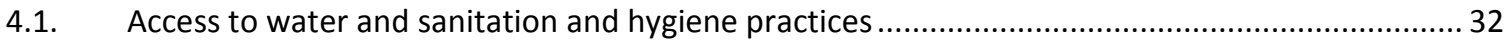

4.2. Vulnerability to climatic events and effects on child health and nutrition................................ 35

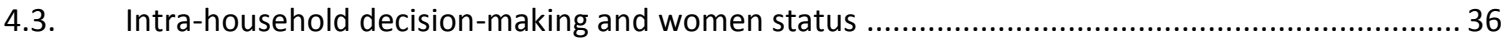

4.4. Summary matrix of quantitative and qualitative findings on the context in the three

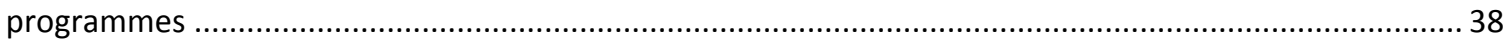

5. Initial qualitative insights into the micro-dynamics of the nutrition intervention ...............................4 41

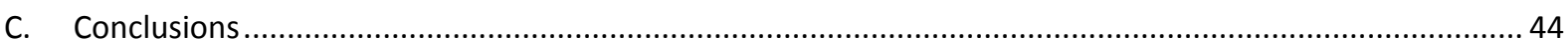

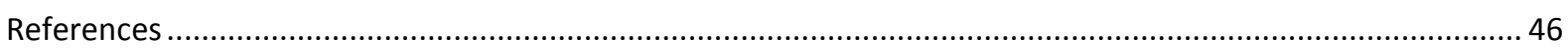

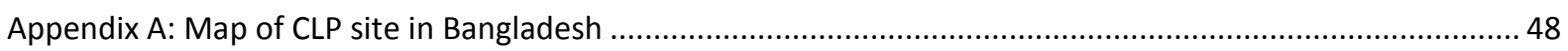

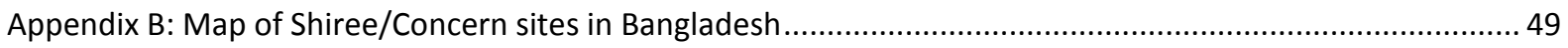

Appendix C: Summary of qualitative methods and samples used ….....................................................5 50

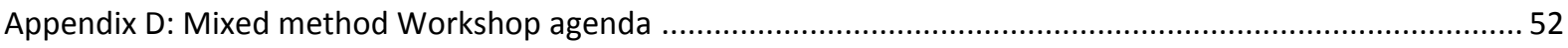




\section{TABLES}

Table 2.1.1: Key features of the three livelihood programmes based on qualitative and quantitative data

Table 2.2.1: Baseline assets transfer by intervention arm - Shiree (based on the quantitative survey) ............. 15

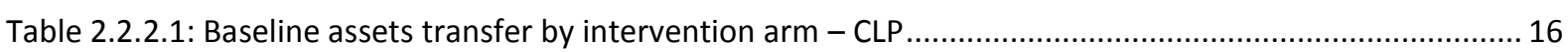

Table 2.2.2.2: Baseline means of access to services by intervention arm - CLP ............................................ 16

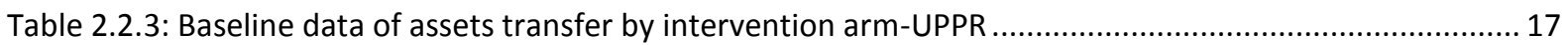

Table 2.4.1: Experiences with the three livelihood programmes and potential impact of nutrition interventions

Table 3.1.1: Nutritional status of children under 5 years in the three programme areas (based on anthropometric measurements in the quantitative baseline survey).

Table 3.2.1.1: Knowledge and action on breastfeeding among mothers (based on the quantitative baseline survey)

Table 3.2.1.2: Knowledge about infant and young child feeding practices (IYCF) among mothers and adolescent girls (based on the quantitative baseline survey).

Table 3.2.2.1: Dietary diversity in the previous day for children aged 6-24 months, as reported by their mothers (based on the quantitative baseline survey)

Table 3.2.2.2: Dietary diversity in the previous day for fathers of children age 6-24 months, reported by mothers of children age 6-24 months (based on the quantitative baseline survey).....

Table 3.3.1: Nutritional status of mothers in the three programme areas (based on anthropometric measurements in the quantitative baseline survey)

Table 3.3.2: Dietary diversity in the previous day for mothers of children age 6-24 months, self-reported (based on the quantitative baseline survey)

Table 3.4.1: Antenatal care for mothers of children age 6-24 months, self-reported (based on the quantitative baseline survey)

Table 3.4.2: Assistance at birth for mothers of children age 6-24 months, self-reported (based on the quantitative baseline survey)

Table 3.5.1: Mixed method matrix on baseline findings on child undernutrition.

Table 4.1.1: Hygiene and sanitation in the home, self-reported (based on the quantitative baseline survey) ... 33

Table 4.1.2: Knowledge of hand washing, mothers and adolescent girls (based on the quantitative baseline survey)

Table 4.1.3: Demographic and socioeconomic conditions (based on the quantitative baseline survey)............ 34

Table 4.2.1: Loss of home and assets due to climatic events (based on the quantitative baseline survey) .........35

Table 4.3.1: Mothers' say/participation in intra-household decision-making, self-reported (based on the quantitative baseline survey)

Table 4.3.2: Mothers' Women's perceived power and control over their lives, self-reported (based on the quantitative baseline survey). 
Table 4.4.1: Mixed method matrix on the context of the three livelihood programmes

Table 5.1: Key features and observed challenges of the nutrition interventions in the three livelihood programmes 


\section{ACKNOWLEDGEMENTS}

The authors of this report gratefully acknowledge the support of DFID, the Chars Livelihoods Programme; the Economic Empowerment of the Poorest Programme (Shiree) and the Urban Partnerships for Poverty Reduction Programme for their facilitation of the survey process and comments on the report; and all beneficiaries within these programmes who consented to participate within the evaluation. We are also grateful to the Dr Linda Waldman at IDS, Dr. Virginia Morrow at the University of Oxford, Young Lives Study and the MQSUN team at PATH for further support and comments. Within the consortium partnership we are grateful to the entire BRAC field team for exceptional work in conducting the fieldwork. We are also particularly grateful to Su Mitchell and Leah Plati for logistical and project support to the evaluation at IDS. 


\section{LIST OF ABBREVIATIONS}

$\mathrm{BF}$

BMI

BRAC

C

CDCs

CLP

DFID

EEP

HAZ

IDS

IYCF

$\mathrm{L}$

$\mathrm{L}+\mathrm{N}$

NGO

SEF

SIF

UPPR

WAZ

WHO

WHZ
Breastfeeding

Body Mass Index

Building Resources Across Community

Comparison group

Community Development Committees

Chars Livelihoods Programme

Department for International Development

Economic Empowerment of the Poorest

height-for-age Z-score

Institute for Development Studies

Infant and Young Child Feeding

Livelihoods only group

Livelihoods and direct nutrition interventions group

Nongovernmental Organisation

Socioeconomic Fund

Settlement Improvement Fund

Urban Partnership for Poverty Reduction

weight-for-age Z-score

World Health Organisation

weight-for-height Z-score 


\section{A.BACKGROUND AND PURPOSE OF THE REPORT}

\section{Introduction}

\subsection{Overview of the programmes and the interventions}

The DFID Programme to Accelerate Improved Nutrition for the Extreme Poor in Bangladesh aims to improve nutrition outcomes for children, mothers and adolescent girls by integrating a number of nutrition interventions with the existing livelihood interventions provided to extremely poor households by three existing programmes in Bangladesh. These three programmes are the Chars Livelihoods Programme (CLP), the Economic Empowerment of the Poorest Programme (EEP) more known under the name Shiree ${ }^{1}$ and the Urban Partnership for Poverty Reduction (UPPR).

The CLP aims to improve the livelihoods and food security of one million extremely poor and vulnerable island char dwellers, covering the remote char islands of the north-western districts of Bangladesh (see Appendix A for a map). The chars are an extremely dynamic living environment with frequent flooding and erosion of land. The current phase of CLP (CLP-2) began in 2010 and follows CLP-1 (2004-2010). CLP-2 will run until 2016 and covers Kurigram, Gaibandha and Jampalpur, as well as the new districts of Lalmonhirat, Nilpharmari, Rangpur, Pabna and Tangail. CLP is managed by Maxwell Stamp and led by the Ministry of Local Government, Rural Development and Cooperatives (MLGRDC).

EEP/Shiree aims to support one million people in rural and urban areas to lift themselves out of extreme poverty and to achieve sustainable livelihoods by 2015. Shiree provides resources to national and international NGOs working in Bangladesh through two main funds: the Scale Fund supports NGOs to take proven approaches to improving the livelihoods of the extreme poor to scale; the Innovation fund supports NGOs to implement innovative approaches to improve livelihoods. This evaluation will focus on one of the scale fund projects of Shiree only- the Economic and Social Empowerment of Extreme Poor (ESEP) Project. ESEP is being implemented by Concern Worldwide in 3 districts located in the Haor basin²: Sunamgonj, Habigonj (Slyhet Division) and Kishoregonj (Dhaka Division) (see Appendix B for a map). The haor basin is flooded every year during the monsoon for a period of 6 to 8 months.

The UPPR aims to improve livelihoods of three million poor and extremely poor people, living in urban areas. It covers ten corporations and 14 municipalities across the country. The urban areas are located on different terrains including on hill sites (prone to landslides, flooding) and flat area. The Programme runs from 2007-2015 and takes a community centred approach to urban poverty reduction. Community Development Committees (CDC) thereby choose and propose their choices of community-based interventions (selected from a list of available interventions) to UPPR.

The programmes vary in their approaches to enhancing the livelihoods of beneficiary communities, households and individuals (see section 2). The additional nutrition package is being implemented more or less uniformly across the three programmes and includes behaviour change communication, micronutrient supplementations and deworming. The nutrition intervention targets households that have

\footnotetext{
${ }^{1}$ Shiree is the Bangla word for steps and an acronym for Stimulating Household Improvements Resulting in Economic Empowerment.

${ }^{2}$ Haor basin: Wetland ecosystem in the North-East of Bangladesh. The saucer shaped shallow depression (also known as a backswamp) covers parts of the Sunamganj, Moulvibazar and Habigonj districts, and stretches as far as the Kishorenganj and Netrokona districts of Bangladesh.
} 
already received the livelihood intervention in the CLP and SHIREE programme areas, whereas the beneficiaries were newly selected for the nutrition intervention in the UPPR area.

This mixed method report is an interim report and is the result of a mixed method workshop conducted in June 2014 in Dhaka.

\subsection{Overview of the impact evaluation and the methods}

The objectives of the impact evaluation are:

1. To assess the impact of the combination of the nutrition interventions with the existing livelihood interventions in three different DFID programmes on nutritional status of children under two years of age and to compare this with the impact of the existing livelihood interventions on nutritional status.

2. To explain this impact, drawing on qualitative and quantitative evidence describing programme specific and wider societal/contextual processes with the potential to impact on programme outcomes; and

3. To assess the cost effectiveness of integrating direct and indirect interventions in the three livelihood programmes and to specify the best delivery model for doing so.

In order to address these objectives, the evaluation has been collecting information since September 2013 on a range of key indicators and surrounding contextual factors. Data collection will be completed by December 2015. A mixed method approach was chosen, combining a repeated cross-sectional quasiexperimental survey design with qualitative research and a cost-effectiveness analysis.

\subsubsection{Quantitative data collection}

The data gathered in the quantitative surveys will allow estimating a numerical measure of the impact of the combined nutrition and livelihoods interventions in the three different DFID programmes on nutritional status of children under two; and will compare this with the impact of the existing livelihoods interventions. The quantitative baseline surveys were administered between September and November 2013 to a total of about 11,340 households across the 3 programmes. The survey included households that received the livelihood intervention at baseline and would start additionally receiving the nutrition intervention following baseline $(\mathrm{L}+\mathrm{N})$, households that received the livelihood intervention at baseline and would continue receiving only this livelihood intervention following baseline (L), and a comparison group that did not receive any intervention at baseline and would continue not to receive any intervention following baseline $(\mathrm{C})$.

\subsubsection{Qualitative data collection}

The first qualitative data collection was conducted between February and April 2014. A case study approach was chosen and qualitative case study communities were purposively selected from the quantitative study sites to reflect 'typical communities' (Bamberger et al. 2012) in the two major intervention groups $(\mathrm{L}+\mathrm{N} ; \mathrm{L})$ in the three programme areas. The concept of saturation (Morse 1995) was employed as a guiding principle for the sample selection within each qualitative study site whereby additional participants were identified and interviewed until new data did not provide any new insights. The purpose of the first qualitative data collection was to gain deeper understanding of the social, cultural and political context within which the interventions are embedded and which are likely to influence the up-take and success of the interventions. The qualitative fieldwork also aimed to shed light on underlying processes and mechanisms that may affect the intervention up-take. 
To gain multiple perspectives into the contexts, perceptions and initial experiences with the interventions qualitative data were collected from different sources (e.g. beneficiaries and nonbeneficiaries, influential community members, elderly, health professionals, staff from the organisations that implement the interventions) and using multiple data collection methods (e.g. interviews, focus groups, mapping exercises, life histories). In Appendix C, details are given of the tools, sample sizes and data collection methods. In total, the team conducted 54 in-depth interviews, 27 detailed life histories, 27 focus group discussions and 9 social mapping exercises. The qualitative field teams spent several weeks in each qualitative site and also conducted several follow-up visits to be able to emerge themselves in the local context and to ensure a rich and comprehensive documentation of usual (rather than one-off non-representative) interactions, contexts and experiences. During the followup visits the team also validates the initial qualitative findings by asking participants to review the findings and confirm/disconfirm the accuracy and sufficiency. To check completeness of the information gathered and to increase the interpretive validity, triangulation was used during the analysis and interpretation stage. For this different members of the evaluation team (including researchers based in Bangladesh and the UK) reviewed the data and provided analytic perspectives for the analysis and interpretation of the data. In addition to this internal process, the qualitative findings were also reviewed by external experts both in Bangladesh and UK. This peer review helped to increase the validity and the credibility of the qualitative findings further.

\subsubsection{Limitations of the qualitative data}

Due to time and resource constraints it was impossible to collect qualitative data in all communities covered in the quantitative survey. Thus the presented qualitative findings are specific to the study communities selected for the qualitative work only. However, the selection of typical communities for the qualitative case studies and the use of multiple strategies (i.e. triangulation, validation, peer review) ensured the collection of credible and trustworthy (Lincoln and Guba 1985) qualitative data that allow in-depth insights into the contexts, facilitators for and barriers to the intervention up-take (see also Bamberger et al.2012 on validity of qualitative methods in impact evaluations). This is not a free standing qualitative study but qualitative work that has been designed to interact, enhance and inform the quantitative impact evaluation. Qualitative data are combined with the quantitative data (and the findings from the literature reviews conducted during the inception phase of this impact evaluation) to provide a more comprehensive assessment and explain the impact of the combined nutrition and livelihood interventions for additional data collection.

\subsubsection{Other data collections and analysis}

A concurrent triangulation design will be employed for the quantitative and qualitative end line data collection with surveys and qualitative research being carried out at the same time (between September and November 2015).

A detailed process evaluation (being conducted between July 2014 and March 2015) and a costeffectiveness analysis (between August 2014 and March 2016) complement the quantitative and qualitative components. Data from these evaluation components were not yet available at the time this report was written, but will prove very useful in refining the observations and conclusions of this report.

\subsection{Purpose of this mixed methods report}

The purpose of this interim mixed method report is to integrate the findings from the quantitative baseline and the first qualitative data collection to establish the context in which the livelihood and 
nutrition interventions are embedded and against which the effectiveness of the interventions will be assessed.

The report collates information on the following three areas:

1. The features, opportunities and challenges of the existing livelihood interventions and their potential effect on nutritional status

2. The nature of child undernutrition and its potential reasons across the 3 programme sites

3. The social, economic and cultural context across the 3 programme sites

The aim is to identify behaviours, conditions and factors that may hinder and/or facilitate the up-take and effectiveness of the nutrition interventions in conjunction with the livelihood interventions.

As the qualitative data collection took place shortly after the nutrition intervention had been rolled out, the report also discusses some initial qualitative insights into the micro-dynamics of nutrition interventions, highlights some of the observed challenges and explores how the nutrition intervention may interact with the existing livelihood programmes.

This report is based on discussions/findings presented at a workshop (at which survey and qualitative data were presented) that took place between $23^{\text {rd }}$ and $24^{\text {th }}$ June 2014 in Dhaka. Please see appendix D for the agenda of the workshop and appendix E for a list of the participants.

\subsection{Structure of the report}

This report is structured in three parts. Part A briefly summarises the background, objectives and methodology of the evaluation and describes the purpose of the mixed method workshop. Part B presents the integrated baseline findings across the three focus areas of this workshop. Quantitative and qualitative findings are presented separately for each programme for the details on the livelihood and nutrition interventions, but together for the underlying reasons for undernutrition and the context as comparability between the programmes was high. Section 1 provides insights into the existing livelihood interventions, Section 2 presents information on child undernutrition and its potential causes in each of the programmes, and Section 3 describes social, economic and cultural contextual factors of the programme sites. Section 4 highlights some of the observed challenges and opportunities of the nutrition intervention. Part $\mathrm{C}$ draws some conclusions from the findings.

The mixed method report complements the standalone (pre-dominantly) quantitative baseline report. 


\section{B. FINDINGS}

\section{Features, benefits and challenges of the three livelihood programmes}

This section integrates quantitative and qualitative data on the key characteristics of the three existing livelihood programmes, beneficiaries' experiences with the programmes, challenges and unintended consequences. The secondary aim of the section is to explore the underlying reasons for why the livelihood programmes did not result in the expected improvements in nutritional status among the beneficiaries. A better understanding of these reasons can help to identify factors that may hinder and/or facilitate the effectiveness of the newly introduced nutrition intervention on children's and mothers' nutritional well-being.

\subsection{Key features of the three livelihood programmes}

Table 2.1.1 presents the key features of the three livelihood programmes as observed and reported by the beneficiaries in the qualitative interviews. While there were a few common features across the three programmes (e.g. targeting of poor and extreme poor households, provision of livelihood support), the data revealed several important differences in the beneficiary selection, the services and assets provided, how they were chosen and delivered.

Table 2.1.1: Key features of the three livelihood programmes based on qualitative and quantitative data

\begin{tabular}{|c|c|c|c|}
\hline Features & Shiree Concern & CLP & UPPR \\
\hline $\begin{array}{l}\text { Beneficiary } \\
\text { selection }\end{array}$ & $\begin{array}{l}\text { Beneficiaries are selected } \\
\text { by SHIREE-Concern directly } \\
\text { Selection criteria: } \\
\text { - } \quad \text { Low or no per capita } \\
\text { income (< BDT 21/day) } \\
\text { - } \quad \text { No access to } \\
\text { microfinance } \\
\text { - Homestead land } 0.3 \\
\text { decimals or less } \\
\text { - No cultivable land }\end{array}$ & $\begin{array}{l}\text { CLP management selects } \\
\text { core-beneficiary } \\
\text { households (household can } \\
\text { be represented by any } \\
\text { member, but are mainly } \\
\text { represented by women as } \\
\text { men migrate) } \\
\text { Selection criteria: } \\
\text { - No landownership } \\
\text { - No regular income } \\
\text { - No outstanding loans } \\
\text { - No recipient of other } \\
\text { grants or social } \\
\text { programmes } \\
\text { - Live in CLP areas for > } \\
6 \text { months }\end{array}$ & $\begin{array}{l}\text { Beneficiaries are identified } \\
\text { through a community-led } \\
\text { approach led by women. } \\
\text { In some communities } \\
\text { beneficiary selection was } \\
\text { based on an out-dated list } \\
\text { of households and did not } \\
\text { consider the high mobility } \\
\text { of dwellers. Consequently, } \\
\text { new poor inhabitants were } \\
\text { excluded, whereas richer } \\
\text { inhabitants who moved } \\
\text { into the houses of previous } \\
\text { poorer dwellers received } \\
\text { benefits unnecessarily. This } \\
\text { led to frustration of new } \\
\text { inhabitants. }\end{array}$ \\
\hline $\begin{array}{l}\text { Services } \\
\text { provided }\end{array}$ & $\begin{array}{l}\text { Livelihood asset (chosen } \\
\text { and provided by } \\
\text { Concern and the } \\
\text { implementing local } \\
\text { NGO) could include } \\
\text { livestock, rickshaws, } \\
\text { sewing machines, } \\
\text { supplies for grocery } \\
\text { stores, boats and nets. } \\
\text { Most households } \\
\text { received poultry (65\%) }\end{array}$ & $\begin{array}{l}\text { Core-beneficiaries: } \\
\text { - } \text { Provision of capital to } \\
\text { purchase productive } \\
\text { asset (e.g. livestock, land } \\
\text { lease, business start-up) } \\
\text { - Ongoing monthly grants } \\
\text { (18 months) for asset } \\
\text { maintenance and } \\
\text { livelihood maintenance } \\
\text { (provision of grants }\end{array}$ & $\begin{array}{l}\text { Two components: } \\
\text { 1. Settlement } \\
\text { Improvement Fund (SIF) } \\
\text { Communities can apply for } \\
\text { funds for infrastructure } \\
\text { improvements including } \\
\text { water and sanitation } \\
\text { facilities, drainage, garbage } \\
\text { disposal sites, roads and } \\
\text { housing }\end{array}$ \\
\hline
\end{tabular}




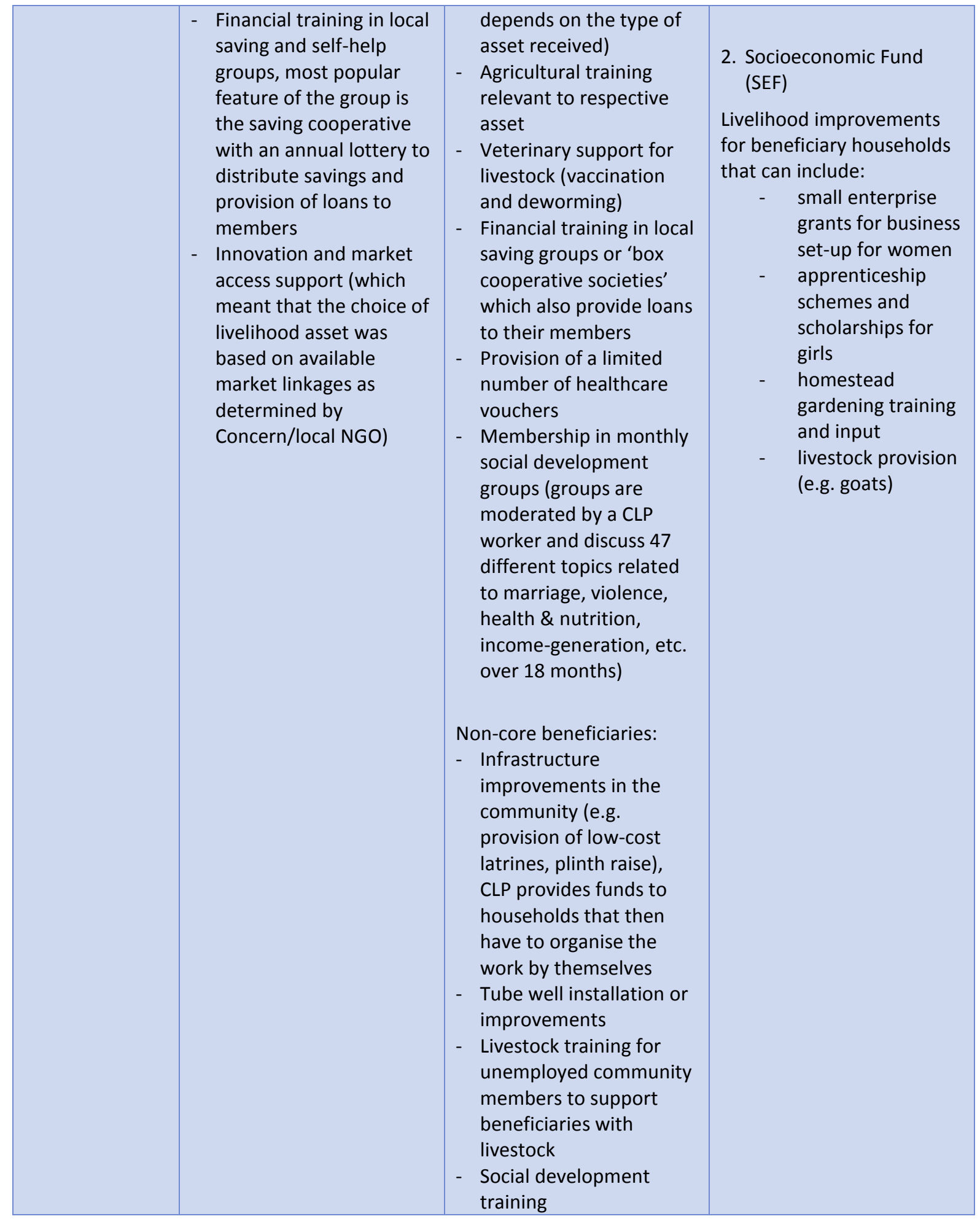




\begin{tabular}{|l|l|l|l|}
\hline Implementation & $\begin{array}{l}\text { Evaluation only assesses } \\
\text { SHIREE -Concern }\end{array}$ & $\begin{array}{l}\text { Local NGOs } \\
\text { (implementation may vary } \\
\text { between char areas } \\
\text { depending on the NGO) } \\
\text { local NGO for } \\
\text { implementation }\end{array}$ & $\begin{array}{l}\text { Community-led } \\
\text { implementation }\end{array}$ \\
$\begin{array}{l}\text { SHIREE is designed by } \\
\text { different local and } \\
\text { international NGOs and not } \\
\text { a central management } \\
\text { agency (as CLP and UPPR). }\end{array}$ & & \\
\hline
\end{tabular}

\subsection{Beneficiaries experiences with the livelihood programmes}

\subsubsection{Shiree}

\section{Mixed experiences with the livelihood assets and services}

In the qualitative fieldwork, beneficiaries indicated both positive and negative personal experiences with the assets and services they had received from the various programmes. Some described how the asset helped them to generate additional household income (e.g. by selling eggs or milk). In a few cases beneficiaries were able to save some of the profits or reinvest profits into new assets for the household (e.g. purchase of land for farming). However, many beneficiaries pointed out that they were not able to sustainably improve their livelihood after joining the programme.

\section{Barriers to successful improvements of livelihoods}

A necessary pre-condition for the successful generation of income with the provided asset was access to local markets and demand for the products. Given that the haor basin is flooded for 6 to 8 months each year, limited accessibility to markets was mentioned as a common challenge or even a barrier to long-term livelihood improvements.

Other frequently perceived barriers were:

- Lack of training on how to use the asset most effectively for income-generation

- No ongoing support for beneficiaries to help, for example, with asset maintenance costs (e.g. fodder)

- Illness and death of the livestock (the SHIREE programme does not provide free-of-charge veterinary support, vaccinations and deworming to the beneficiaries)

\section{Perceived inequalities and frustrations with the livelihood assets}

Several beneficiaries were disappointed that they had not received the livelihood asset they had wished for but a different one. A frustrated beneficiary said that she had requested a dairy cow to be able to produce and sell milk and thus supplement the household income on an ongoing basis. However, she received seed potatoes and support to lease land for potato farming. The woman began to cultivate potatoes but believed that it consumed a lot of her time and kept her from other more profitable tasks and income-generating activities. Overall, she felt that the livelihood programme contributed to a decrease in her overall income rather than an improvement. 
According to the quantitative survey most households received low-budget assets such as poultry (68\%) rather than high-budget and more desired cows or cattle (Table 2.2.1)

Table 2.2.1: Baseline assets transfer by intervention arm - Shiree (based on the quantitative

\section{survey)}

\begin{tabular}{|lcc|}
\hline & $(\mathbf{L + N})(\%)$ & $(\mathbf{L})(\%)$ \\
\hline Heifer & 1 & 1 \\
\hline Beef cattle & 0 & 0 \\
\hline Dairy cow & 1 to 2 & 1 \\
\hline Sheep & 16 & 16 \\
\hline Goat & 9 & 9 \\
\hline Chicken, duck, goose and other poultry & 68 & 65 \\
\hline Sewing machine & 2 & 2 \\
\hline Rickshaw/van & 2 & 1 \\
\hline Boat & 11 & 10 \\
\hline Fishing net & 5 & 6 \\
\hline Land or pond share/lease/mortgage/purchase & 17 & 22 \\
\hline Other & 13 & 13 \\
\hline
\end{tabular}

Note: $(L+N)=$ households receiving both the livelihoods and nutrition interventions, $(L)=$ households receiving the livelihoods intervention only.

There were also some perceived inequalities with regards to the distribution of the services and support recipients received. The extent of the support provided was usually not adjusted to the number of household members it was meant to support. This meant that a household with only three members would receive the same livelihood asset as a household with 8 household members. As the generated income was likely to be similar, the overall impact on the household's economic well-being would be considerably higher in the smaller household.

\section{Women's empowerment}

Women typically took responsibility for the livestock asset and generated income from it. Some women described how they felt supported by this new opportunity and how it increased their self-worth and intra-household bargaining power in decision-making. They also enjoyed increased mobility within and outside the community thanks to the intervention (e.g. going to the market to sell products). Female beneficiaries also felt more confident thanks to the saving and self-help groups established as part of the programme.

Most women favoured the saving component and praised the financial training they received (between $46-61 \%$ according to the survey). The saving cooperative was liked as it provided opportunities an easy access to loans in times of financial hardship - the loans were perceived as particularly important as it helped them to avoid exploitation by local money lenders. The cooperative also organised annual lotteries to distribute the saved funds.

The self-help component was generally perceived as less influential, although it helped to raise awareness of issues that affected the women in the community (e.g. child care, disaster preparedness).

\subsection{2. $C L P$}

\section{Satisfaction with the livelihood assets and services}

In the qualitative interviews the majority of CLP beneficiaries voiced satisfaction with the programme and services they had received. They especially appreciated the support to purchase livestock and 
stressed how important it was for them to be able to choose the livestock asset best suited to their needs (in contrast to Shiree where livestock was chosen and provided by Concern/local NGO).

According to the quantitative survey, most beneficiaries (98 to 99\%) received a cow (heifer, beef cattle or dairy cow; see Table 2.2.2.1).

\section{Table 2.2.2.1: Baseline assets transfer by intervention arm - CLP}

\begin{tabular}{|lcc|}
\hline & $(\mathbf{L + N )}(\mathbf{\%})$ & (L) (\%) \\
\hline Heifer & 59 & 59 \\
\hline Beef cattle & 24 & 23 \\
\hline Dairy cow & 14 & 16 \\
\hline Sheep & 4 & 5 \\
\hline Goat & 9 & 6 \\
\hline Chicken, duck, goose and other poultry & 5 & 3 \\
\hline Other & 30 & 29 \\
\hline
\end{tabular}

Note: $(L+N)=$ households receiving both the livelihoods and nutrition interventions, $(L)=$ households receiving the livelihoods intervention only.

Additional to the livelihood assets, the majority of beneficiaries reported receiving regular livelihood and asset maintenance cost stipends, agricultural training, and financial training as part of the saving groups, and some basic health and nutrition education in the social development groups (see Table 2.2.2.2).

Table 2.2.2.2: Baseline means of access to services by intervention arm - CLP

\begin{tabular}{|c|c|c|}
\hline & $(\mathrm{L}+\mathrm{N})(\%)$ & (L) (\%) \\
\hline Livelihood Maintenance Stipend & 95 & 97 \\
\hline Asset Maintenance Cost Stipend & 99 & 99 \\
\hline Agricultural Livelihood Training & 91 & 94 \\
\hline Non-agricultural Livelihood Training & 7 & 6 \\
\hline Financial Training & 87 & 86 \\
\hline Health and Nutrition Training & 88 & 86 \\
\hline
\end{tabular}

Note: $(L+N)=$ households receiving both the livelihoods and nutrition interventions, $(L)=$ households receiving the livelihoods intervention only.

\section{Women's empowerment}

As most men migrated for work for several months each year, women usually took responsibility for the livestock. This provided welcome income-generating opportunities for women as they could sell produce including eggs, milk or poultry at local markets for cash. Several women explained how the capacity of earning cash income had increased their status in their household and their community. While the majority (>90\%) of women in CLP reported to be engaged in paid work, females were often paid in kind (e.g. food) instead of cash. Access to cash was perceived as empowering because it enabled women to buy essential goods and services of their choice. Mobility of women also increased as they had to access local markets regularly to sell their produces. In this context several women pointed out that access to markets was often impossible due to flooding and inaccessible roads during rainy season. To counteract income loss a few women try to sell their products to neighbours and (if available) cooperatives (e.g. milk cooperatives).

Female beneficiaries also described how the box cooperative society (a community-based saving group founded as part of the livelihood intervention) improved their sense of control and security as it offered 
the opportunity to ask for loans in times of financial hardships (e.g. flooding, illness, loss of crops). The actual livelihood asset provided additional security as it could be sold if necessary.

\section{Sanitary improvements and challenges}

Both beneficiaries and non-beneficiaries highlighted the improvements of sanitary conditions in the communities thanks to the new low-cost latrines provided by CLP. However, many recipients complained about the low sustainability of the bamboo walls that were built around the latrines to ensure privacy. Water damage and insect infestations often damaged and destroyed the walls after a few months and households often did not have the funds or did not perceive it as their responsibility to replace the walls. These households often returned to open defecation practices according to the qualitative interviews.

\section{Problems and complaints}

Many households described how they had used the monthly maintenance grants as additional household income rather than to purchase fodder for the livestock (fodder was often collected free-of-charge from the fields by children or women). After graduation from the programme, households missed these income supplements and struggled to adjust their household expenditures.

A small number of cows also had died due to illness and lack of resources to pay for veterinary treatment after the programme and associated support had ended.

\subsection{3. $U P P R$}

Improvements in the communities infrastructure including repairs and installations of drainage systems and provision of sanitation facilities was perceived as one of the main benefit of the UPPR programme. The quantitative data provided some evidence for the success of these improvements, with a majority of households in UPPR communities reporting access to sanitary latrines and safe drinking water (Table 2.2.4).

However, beneficiaries pointed out that not all infrastructure improvements were welcome in the community and that conflicts about access and use of land had resulted in the early termination of some projects such as the construction of drainage systems. To prevent premature ends of projects in the future it is important to include all relevant stakeholders and inhabitants in the planning and decision making processes from the beginning.

\section{Negative experiences with individual-level livelihood support}

UPPR beneficiaries had less positive experiences with the individual livelihood support they received. Based on the quantitative survey, approximately one third of the beneficiaries received 'other' assets including supplies for setting up a grocery store, seeds for home gardening, or a rickshaw. Only few beneficiaries (12\%) received livestock (mainly poultry) (Table 2.2 .3 ).

\section{Table 2.2.3: Baseline data of assets transfer by intervention arm-UPPR}

\begin{tabular}{|lcc|}
\hline & $(\mathbf{L}+\mathbf{N})(\%)$ & $(\mathbf{L})(\%)$ \\
\hline Heifer & 1 & 0 \\
\hline Goat & 2 & 2 \\
\hline Chicken, duck, goose and other poultry & 9 & 12 \\
\hline Sewing machine & 1 & 1 \\
\hline Other & 33 & 35
\end{tabular}

Note: $(L+N)=$ households receiving both the livelihoods and nutrition interventions, $(L)=$ households receiving the livelihoods intervention only. 
According to the qualitative data, only very few beneficiaries were able to use their assets effectively and sustainably to generate income. The majority of beneficiaries experienced external environmental, spatial and political adversities that prevented success.

Several beneficiaries who had received poultry lost their entire livestock due to poisoning in an urban campaign to combat mosquitoes that involved large-scale spraying of insecticides (Chittagong is severely affected by dengue fever that is spread by infected mosquitoes (Rahman, Haughton et al. 2010)). Lack of space in densely populated urban settlements made home-gardening or livestock rearing impossible and often led to conflicts with neighbours. Political tensions and violent hartals ${ }^{3}$ in the lead up to the January 2014 elections prevented the successful launch of small shops as their owners were afraid to leave their homes due to security risks.

Security concerns and fears of becoming victim to sexual violence was regularly expressed as a major barrier for female participation in income-generating activities and attendance of capacity building training sessions offered by the programme. These concerns might in part explain the very low participation of women in the work force in urban areas found in the quantitative survey (68\% of women reported not to work).

According to the quantitative survey hardly any households receive training (e.g. financial training) or other services (e.g. asset maintenance cost stipends) from the programme.

\subsection{Perceptions of why the livelihood intervention did not result in an improvement in nutrition in the study communities}

In both CLP and SHIREE study communities (to some extent), women reported in qualitative interviews that the livelihood transfer enabled them to produce protein-rich foods (e.g. eggs, milk) and nutrients-rich fruits and vegetables (e.g. home-gardening, farming). Most women indicated that their household usually consumed small amounts of these products (especially the products of low quality and during rainy season when access to markets was challenging). The majority of products was sold at local markets, to neighbours or to cooperatives. The generated money was used to purchase a variety of essential services (e.g. healthcare, transport, essential repairs, education) and products (e.g. dry goods and staples such as rice, salt, snacks, oil, soap and cooking fuel). The purchase of staple foods was perceived as particularly important to prepare for times of food scarcity and to be able to feed the entire household regularly. If possible, women also saved some of the money for unexpected crises.

In UPPR only few households were able to successfully use the livelihood support and assets to generate income and/or foods.

\subsection{Summary matrix of quantitative and qualitative findings on the three livelihood programmes}

Table 2.4.1 presents the combination of the quantitative and qualitative data on the three livelihood intervention and highlights factors that may influence the effectiveness of the nutrition interventions in the context of each of the programmes.

\footnotetext{
${ }^{3}$ Hartals: General strikes that often involve closure of schools and places of business. It is a mode of appealing to the sympathies of a government to change an unpopular or unacceptable decision.
} 
Table 2.4.1: Experiences with the three livelihood programmes and potential impact of nutrition interventions

\begin{tabular}{|c|c|c|c|}
\hline Programme & Quantitative & Qualitative & $\begin{array}{l}\text { Potential influence on the } \\
\text { effectiveness of the } \\
\text { nutrition intervention }\end{array}$ \\
\hline Shiree & $\begin{array}{l}\text { Livelihood asset: most } \\
\text { beneficiaries received } \\
\text { poultry, access to } \\
\text { land/pond or sheep } \\
\text { Other services: financial } \\
\text { training }\end{array}$ & $\begin{array}{l}\text { Mixed experiences with livelihood } \\
\text { intervention } \\
\text { Perceived barriers to successful } \\
\text { livelihood improvement included } \\
\text { limited access to markets during the } \\
6 \text { to } 8 \text { months of flooding each year, } \\
\text { lack of training and support with the } \\
\text { livelihood asset provided, illness and } \\
\text { death of livestock as no financial } \\
\text { means to purchase medication, } \\
\text { deworming and vaccination } \\
\text { Dissatisfaction with asset received as } \\
\text { it often did not correspond with their } \\
\text { choice or request } \\
\text { Women felt empowered by the } \\
\text { ability to earn cash and contribute to } \\
\text { household expenditures } \\
\text { Saving group was most popular } \\
\text { feature of programme as it offers } \\
\text { uncomplicated loans and avoids } \\
\text { exploitations by money lenders loans } \\
\text { Livelihood products (eggs, milk, and } \\
\text { vegetable) were sold and (to a small } \\
\text { extent) consumed by household. } \\
\text { Cash income was perceived as } \\
\text { important to purchase essential } \\
\text { services and products of their own } \\
\text { choice }\end{array}$ & $\begin{array}{l}\text { Poor households valued } \\
\text { cash income to obtain } \\
\text { necessary goods and } \\
\text { services of their choice. } \\
\text { Own consumption of } \\
\text { nutritious foods means loss } \\
\text { of profit (Can behaviour } \\
\text { change education make a } \\
\text { difference?) } \\
\text { Infrastructural } \\
\text { improvements (water and } \\
\text { sanitation services, } \\
\text { housing) are not part of the } \\
\text { programme but poor } \\
\text { infrastructure might pose a } \\
\text { major barrier to } \\
\text { improvements in child } \\
\text { health and nutrition }\end{array}$ \\
\hline CLP & $\begin{array}{l}\text { Livelihood asset: most } \\
\text { beneficiaries received a } \\
\text { cow } \\
\text { Other services: most } \\
\text { beneficiaries received } \\
\text { agricultural training, } \\
\text { financial training, health } \\
\text { \& nutrition education as } \\
\text { part of the social } \\
\text { development group, } \\
\text { livelihood and asset } \\
\text { maintenance cost } \\
\text { stipends }\end{array}$ & $\begin{array}{l}\text { High level of satisfaction with the } \\
\text { programme and asset received } \\
\text { Women felt empowered by ability to } \\
\text { earn cash and contribute to } \\
\text { household expenditures } \\
\text { Saving group is popular feature of } \\
\text { programme as it offers loans } \\
\text { Access to markets can be challenging } \\
\text { and can prevent selling of products } \\
\text { - Infrastructure improvements are } \\
\text { part of the project, however, } \\
\text { some challenges as improvements } \\
\text { often not maintained }\end{array}$ & $\begin{array}{l}\text { Poor households valued } \\
\text { cash income to obtain } \\
\text { necessary goods and } \\
\text { services of their choice. } \\
\text { Own consumption of } \\
\text { nutritious foods means loss } \\
\text { of profit (Can behaviour } \\
\text { change education make a } \\
\text { difference?) }\end{array}$ \\
\hline
\end{tabular}




\begin{tabular}{|c|c|c|c|}
\hline UPPR & $\begin{array}{l}\text { Livelihood asset: only } \\
\text { very few beneficiaries } \\
\text { received assets } \\
\text { Other services: almost no } \\
\text { household received } \\
\text { training }\end{array}$ & $\begin{array}{l}\text { Improvements in communities' } \\
\text { infrastructure praised by } \\
\text { beneficiaries } \\
\text { Local power struggles about land use } \\
\text { can prevent improvements of } \\
\text { infrastructure } \\
\text { External environmental, spatial and } \\
\text { political barriers to the use of assets } \\
\text { for income-generating activities } \\
\text { Security concerns prevent } \\
\text { participation of women }\end{array}$ & $\begin{array}{l}\text { Infrastructure } \\
\text { improvements are an } \\
\text { important part of the } \\
\text { programme and might } \\
\text { facilitate improvements in } \\
\text { child health and nutrition } \\
\text { independent of nutrition } \\
\text { intervention }\end{array}$ \\
\hline
\end{tabular}

\section{The nature of child undernutrition and its potential reasons across the 3} programme sites

\subsection{The manifestation of child undernutrition}

Child undernutrition according to anthropometric measures is prevalent in all three programmes. Stunting rates are very high (45\% of children under 5 years) in the Shiree programme area, high (32$35 \%$ ) in CLP, and medium (25-28\%) in UPPR (based on the WHO's classification for assessing severity of malnutrition by prevalence ranges among children under 5 years of age) (WHO 2014). The prevalence of child wasting is high to very high in all three programmes areas, while prevalence of underweight is very high in Shiree and high in CLP and UPPR (see Table 3.1.1).

Table 3.1.1: Nutritional status of children under 5 years in the three programme areas (based on anthropometric measurements in the quantitative baseline survey)

\begin{tabular}{|l|c|c|c|}
\hline & Shiree, (\%) & CLP, (\%) & UPPR, (\%) \\
\hline Nutrition indicator & $\mathbf{L ~ L + N ~}$ & $\mathbf{L}$ L+N & L+N \\
\hline Child $<5$ years) & \multicolumn{3}{|c|}{} \\
\hline Stunting (HAZ <-2) & 45 & 32 to 35 & 25 to 28 \\
\hline Wasting (WHZ<-2) & 16 to 18 & 15 & 13 to 15 \\
\hline Underweight (WAZ<-2) & 38 to 41 & 29 to 31 & 22 to 23 \\
\hline
\end{tabular}

$H A Z=$ height-for-age $z$-score $; W H Z=$ weight-for-age $z$-score $; W A Z=$ weight-for-age $z$-score. The range in the tables refers to the range in the percentages between Land $L+N$ intervention sites.

The findings from the qualitative interviews with community members suggest a lack of perceptions of child undernutrition. Generally, child undernutrition was not recognised as a major problem or a priority in the community. Although, thin or visibly undernourished children were often described as 'nutritionless children', whereas fat children were seen as 'doing perfectly in nutrition aspects'. A child's nutritional well-being was solely related to his/her weight (and not to his/her height).

Some parents explained their children's thinness by referring to "low digestive powers" and pointed out that:

If digestive power is high, one [the child] can consume everything [and is well-nourished].

[Mother, CLP] 
Given the high proportion of undernourished children in each study site, parents' expectations of their children's body weight may also be shaped by the nutritional status of the other children in the neighbourhood. This may create the conviction that undernutrition is just part of the "normal order of things' in their community.

Nevertheless, community members perceived a strong association between a child's low weight and his/her ability to work and do daily household's chores. Moreover, well-nourished children were often described as healthy, whereas undernourished children were perceived as unhealthy and unable to work.

Most parents did not see an immediate link between that their children's nutritional status and their future health, well-being, educational outcomes and income generating opportunities.

\subsection{Child feeding practices}

\subsubsection{Breastfeeding}

According to the quantitative data the majority of children below the age of 6 months were breastfed in all three study sites (Table 3.2.1.1). This corroborates findings from the latest Demographic and Health Survey (DHS) in Bangladesh that found breastfeeding to be almost universal in Bangladesh (DHS 2013).

Table 3.2.1.1: Knowledge and action on breastfeeding among mothers (based on the quantitative baseline survey)

\begin{tabular}{|l|c|c|c|}
\hline & Shiree, (\%) & $\begin{array}{c}\text { CLP, (\%) } \\
\text { IYCF knowledge }\end{array}$ & $\begin{array}{c}\text { UPPR, (\%) } \\
\text { L L+N }\end{array}$ \\
\hline $\begin{array}{l}\text { Mothers (15-49 years) } \\
\begin{array}{l}\text { Heard and acted on information } \\
\text { about commencing BF within 1 hr of } \\
\text { birth }\end{array}\end{array} \quad 97$ to 98 & 97 to 98 \\
\hline $\begin{array}{l}\text { Heard and acted on information } \\
\text { about exclusive BF }\end{array}$ & 81 to 83 & 83 to 84 & 83 to 85 \\
\hline
\end{tabular}

$I Y C F=$ Infant and Young Child Feeding; BF= breastfeeding. The range in the tables refers to the range in the percentages between $L$ and $L+N$ intervention sites.

The quantitative baseline survey also found that most mothers had knowledge about the importance of exclusive breastfeeding, early initiation and the benefits of the colostrum in all three programme sites (more than $80 \%$ of mothers answered the breastfeeding knowledge questions correctly). The knowledge levels about breastfeeding among adolescent girls were slightly lower; nevertheless more than $50 \%$ of all girls answered the questions correctly (Table 3.2.1.2). 
Table 3.2.1.2: Knowledge about infant and young child feeding practices (IYCF) among mothers and adolescent girls (based on the quantitative baseline survey)

\begin{tabular}{|c|c|c|c|}
\hline & Shiree, (\%) & CLP, (\%) & UPPR, (\%) \\
\hline IYCF knowledge & $\mathbf{L} \quad \mathbf{L}+\mathbf{N}$ & $\mathbf{L} \quad \mathbf{L}+\mathbf{N}$ & $\mathbf{L} \quad \mathbf{L}+\mathbf{N}$ \\
\hline \multicolumn{4}{|l|}{ Mothers (15-49 years) } \\
\hline $\begin{array}{l}\text { Score on nutrition knowledge test (of } \\
\text { 10) }\end{array}$ & 6.39 to 6.47 & 7.40 to 7.42 & 7.46 to 7.53 \\
\hline $\begin{array}{l}\text { Knows when should a baby start } \\
\text { getting breast milk (\%) }\end{array}$ & 83 to 84 & 90 to 91 & 90 to 92 \\
\hline $\begin{array}{l}\text { Knows what should mother do with } \\
\text { colostrum (\%) }\end{array}$ & 87 to 89 & 85 to 86 & 85 to 86 \\
\hline $\begin{array}{l}\text { Knows at what age babies should be } \\
\text { given other foods (\%) }\end{array}$ & 53 & 63 & 74 to 75 \\
\hline $\begin{array}{l}\text { Knows what seasoning is fortified } \\
\text { with iodine (\%) }\end{array}$ & 26 to 27 & 57 & 56 to 62 \\
\hline \multicolumn{4}{|l|}{ Adolescent girls } \\
\hline $\begin{array}{l}\text { Score on nutrition knowledge test (of } \\
\text { 10) }\end{array}$ & 5.65 to 6.09 & 6.48 to 6.68 & 6.74 to 6.94 \\
\hline $\begin{array}{l}\text { Knows when should a baby start } \\
\text { getting breast milk (\%) }\end{array}$ & 54 to 67 & 65 to 68 & 73 to 74 \\
\hline $\begin{array}{l}\text { Knows what should mother do with } \\
\text { colostrum (\%) }\end{array}$ & 62 to 65 & 60 to 73 & 68 to 71 \\
\hline $\begin{array}{l}\text { Knows at what age babies should be } \\
\text { given other foods (\%) }\end{array}$ & 43 to 46 & 54 to 56 & 58 to 63 \\
\hline $\begin{array}{l}\text { Knows what seasoning is fortified } \\
\text { with iodine (\%) }\end{array}$ & 37 to 54 & 66 to 72 & 71 to 76 \\
\hline
\end{tabular}

IYCF = Infant and Young Child Feeding. The range in the tables refers to the range in the percentages between $L$ and $L+N$ intervention sites.

Despite high awareness of both the benefits of breastfeeding and the importance of early initiation of breastfeeding practices, as well as fairly high self-reports of following these practices, mothers frequently reported prelactael feeding in the qualitative interviews. The most common foods given to a new-born were honey ('to help children talk sweetly') or sugar water if honey was not available and seed oils. In some communities of the CLP programme, cow or goat milk was fed to the new-borns as colostrum was perceived as harmful for health. Prelactael feeding practices and beliefs had a long tradition in the communities (especially rural communities) and were actively encouraged by relatives (e.g. mother-in-laws, elderly), despite health workers advice against them. Given that approximately $71 \%$ of all births in Bangladesh are delivered at home (DHS 2011), relatives often have immediate access to the new-born and can actively promote prelactael feeding. Health facility-based breastfeeding promotions (e.g. WHO/UNICEF baby-friendly hospital initiative) do not reach mothers who deliver at home (Haider et al. 2000). Studies on prelactael feeding practices have shown that the provision of food or drink prior to the initiation of breastfeeding can delay milk production (as it delays breastfeeding) and can pose an important barrier to the establishment of good breastfeeding practices (FU, Rahmani et al. 1996, Nguyen, Keithly et al. 2013, Sundaram, Labrique et al. 2013). In addition, a cohort study from urban Bangladesh by Mihrshali et al. (2008) found that children who were exclusively or predominately breastfed were significantly less likely to suffer from diarrhoea and acute respiratory infections in the first 6 months of life. 


\subsubsection{Complementary feeding practices}

\section{Barriers to the provision of varied and nutritious foods}

Quantitative findings show that most mothers had some knowledge about adequate complementary feeding practices (e.g. age of initiation, the benefits of feeding animal-source foods and responsive feeding), with the majority of mothers responding correctly to a question about the age at which complementary feeding should be introduced (53\% of mothers in Shiree, 63\% in CLP, 74 to $75 \%$ in UPPR; See Table 2.2.1.2). Knowledge levels about healthy complementary feeding practices were lower among adolescent girls.

The qualitative data support these findings and additionally highlight that mothers had a good awareness of what constitutes a nutritious diet for both children and adults. Fish, meat, dairy and eggs as well as vegetable and fruits were perceived as nutritious foods. Legumes were generally not mentioned despite the high protein and micronutrients content.

However, while there was awareness about the components of a nutritious diet, quantitative analysis of complementary foods given to children aged between 6 and 24 months suggested that children's dietary diversity was low on average (Table 3.2.2.1). Based on mothers' recall of foods consumed by their children during the last 24 hours, children mainly ate cereals (e.g. rice), tubers and roots and 'other vegetables' (not Vitamin-A-rich and not leafy greens). Consumption of protein-rich foods (including animal-source foods and legumes) was low. Children's dietary diversity tended to be lowest in Shiree areas, followed by CLP, followed by UPPR.

Table 3.2.2.1: Dietary diversity in the previous day for children aged 6-24 months, as reported by their mothers (based on the quantitative baseline survey)

\begin{tabular}{|c|c|c|c|}
\hline & Shiree, (\%) & CLP, (\%) & UPPR, (\%) \\
\hline Children's dietary diversity & L $\quad \mathbf{L}+\mathbf{N}$ & $\mathbf{L} \quad \mathbf{L}+\mathbf{N}$ & L $\quad \mathbf{L}+\mathbf{N}$ \\
\hline Consumed Cereal yesterday (\%) & 89 to 90 & 89 to 91 & 88 \\
\hline Consumed Vit A rich veg yesterday (\%) & 2 to 3 & 8 to 10 & 5 to 6 \\
\hline $\begin{array}{l}\text { Consumed White tubers/roots yesterday } \\
\text { (\%) }\end{array}$ & 56 & 56 to 59 & 68 to 70 \\
\hline Consumed Green leafy veg yesterday (\%) & 22 to 28 & 35 to 36 & 28 to 29 \\
\hline $\begin{array}{l}\text { Consumed Other vegetables yesterday } \\
(\%)\end{array}$ & 69 & 71 to 72 & 74 \\
\hline Consumed Vit A rich fruits yesterday (\%) & 1 & 2 to 3 & 2 to 3 \\
\hline Consumed Other fruits yesterday (\%) & 17 to 21 & 20 to 23 & 24 \\
\hline Consumed Meat yesterday (\%) & 3 & 6 & 11 to 12 \\
\hline Consumed Eggs yesterday (\%) & 5 to 7 & 12 to 13 & 22 to 25 \\
\hline Consumed Fish yesterday (\%) & 54 to 55 & 34 to 35 & 34 \\
\hline $\begin{array}{l}\text { Consumed Beans peas lentils yesterday } \\
\text { (\%) }\end{array}$ & 18 to 21 & 16 & 35 to 40 \\
\hline Consumed Dairy yesterday (\%) & 8 & 21 to 22 & 30 to 31 \\
\hline Number of groups yesterday (of 12) & 3.4 to 3.6 & 3.8 & 4.2 to 4.3 \\
\hline
\end{tabular}

The range in the table refers to the range in the percentages between $L$ and $L+N$ intervention sites.

The qualitative data corroborated these findings and highlighted that most households were not able to afford nutritious foods and in particular animal-source foods on a regular basis. Several mothers pointed out that high food prices and lack of a stable income often only allowed them to buy and consume rice or potatoes with salt and chili. 
"Can poor people eat good food (fish-meat) daily? They eat vegetables"

[Health Worker, CLP area]

"Apple, grapes, meat, milk, eggs - these are good food but we cannot afford to give them [our children] anything except potato! I collect whatever green leaves, dry fishes I get from nearby places and cook them. If I buy rice, then I lack the money to buy vegetables even!"

[Life history study, Shiree]

"We eat what we can manage which generally includes rice, fish, and vegetables. Sometimes we can manage meat and sometimes have to eat with alu vorta (mashed potato) only."

[FGD participant, UPPR]

Geographical accessibility of fresh vegetables and fruit was another barrier to a varied complementary diet in CLP, Shiree and UPPR. In CLP and Shiree wet markets that sold fresh produces were often inaccessible during the rainy season and flooding. In Shiree homestead food production such as home gardening to increase and ensure better availability of fresh produces was often impossible because of physical constraints (e.g. frequent flooding, crowed living environments, conflicts around land use). Due to security concerns (e.g. risk of sexual harassment, communal unrests) women in UPPR were often afraid to leave their homes and frequently only shopped at nearby corner stores that mainly stocked dry goods.

\section{Coping with household food insecurity}

To fulfil their children's dietary needs as best as possible even in times of food scarcity many mothers favoured their children (especially young children) in the intra-household food allocation often at a disadvantage of their own needs. As one mother in UPPR explains:

"How can I eat when I cannot give my children [food] properly?"

[FGD participant, UPPR]

Skipping meals or having only two meals per day (instead of three) were other common coping strategies to reduce food consumption and save expensive cooking fuel.

\section{Age-appropriate foods}

Quantitative data show that the dietary patterns of young children ages 6-24 months were very similar to the dietary patterns of older household members. Dietary recall for the previous day for fathers, mothers, and adolescent girls in the same household showed very similar foods consumed (although with slightly higher frequencies consumed by adults). (Table 3.2.2.2). 
Table 3.2.2.2: Dietary diversity in the previous day for fathers of children age 6-24 months, reported by mothers of children age 6-24 months (based on the quantitative baseline survey)

\begin{tabular}{|l|c|c|c|}
\hline & Shiree, (\%) & CLP, (\%) & UPPR, (\%) \\
\hline Fathers' dietary diversity & $\mathbf{L} \mathbf{L + N}$ & $\mathbf{L}$ L+N & L+N \\
\hline Consumed Cereal yesterday (\%) & 96 to 97 & 93 to 94 & 98 to 99 \\
\hline Consumed Vit A rich veg yesterday (\%) & 3 to 4 & 13 & 83 to 85 \\
\hline $\begin{array}{l}\text { Consumed White tubers/roots yesterday } \\
\text { (\%) }\end{array}$ & 70 & 69 to 71 & 39 to 42 \\
\hline Consumed Green leafy veg yesterday (\%) & 30 to 32 & 44 & 92 to 93 \\
\hline Consumed Other vegetables yesterday (\%) & 88 & 87 & 3 \\
\hline Consumed Vit A rich fruits yesterday (\%) & 1 to 2 & 3 & 18 to 19 \\
\hline Consumed Other fruits yesterday (\%) & 12 to 14 & 12 to 14 & 18 to 21 \\
\hline Consumed Meat yesterday (\%) & 3 to 4 & 7 to 8 & 50 to 51 \\
\hline Consumed Eggs yesterday (\%) & 4 to 5 & 46 to 48 & 48 to 49 \\
\hline Consumed Fish yesterday (\%) & 77 to 80 & 22 & 12 to 13 \\
\hline Consumed Beans peas lentils yesterday (\%) & 21 to 25 & 11 to 12 & 4.9 to 5.0 \\
\hline Consumed Dairy yesterday (\%) & 3 to 4 & 4.2 & \\
\hline Number of groups yesterday (of 12) & 4.1 & & \\
\hline
\end{tabular}

The range in the table refers to the range in the percentages between $L$ and $L+N$ intervention sites.

Qualitative data supports this finding. Mothers generally did not prepare special dishes to address their young children's specific dietary needs (e.g. with regards to consistency, frequency, amounts). Children were usually fed the same food as adult household members in all three sites. As a mother in the UPPR study community describes:

"We cannot manage enough food items for cooking. How can we cook separately for children? Adults and children eat the same".

[FGD, UPPR]

To make family food more suitable for very young children, some mothers mentioned that they mashed food or removed spicy gravy. However, most mothers had limited knowledge on how to convert the family food into age-appropriate food. Previous studies from Bangladesh also highlighted that the consistency of complementary food provided to children was often inappropriate and may lead to deficiencies in energy and nutrients (Kimmons et al. 2005; Rasheed et al. 2009, Helen Keller International 2001).

\section{Barriers to responsive feeding}

While the quantitative research indicated that mothers had some knowledge about responsive feeding practices (e.g. most were able to suggest at least one or two ways to encourage a child that does not want to eat), in the qualitative data, several mothers pointed out that lack of time due to work commitments, household chores and care for other children/elderly household members often did not allow them to actively encourage children to eat during family meals. In many households (especially in CLP and Shiree) mothers worked outside the home (e.g. agricultural labour) and young children were left in the care of older children or elderly relatives. These family members may not be aware or have the resources to practice responsive feeding. Non-responsive feeding may result in inadequate consumption both in terms of quantity and quality foods (as has been shown by a previous study from Bangladesh (Moore et al. 2006)). 
Mothers described different strategies for how they dealt with children's refusal to eat. Many mothers said they had to force their children to eat the food provided as no other food was available. This practice was often perceived as the only way of ensuring that the child eats sufficient amounts of food. Other mothers provided cheap, store-bought snacks (e.g. biscuits, chips, fried snacks) between meals or to replace meals (especially when there was a shortage of fuel to cook). Provision of snacks (including high fat and sugar 'Western-style' snacks) was also a common strategy to stop children from crying. Breastfeeding was another practice to provide quick nutrition to children older than 6 months, as spoon or hand feeding was difficult and time-consuming. One mother described:

"I know, it is good if the baby eats rice, vegetables. But he nags so much whenever I try to feed him rice, so I just give him breast milk and stop him crying. I have so many chores to do that I cannot spend long time to feed him only."

[FGD, Shiree]

This practice may lead to inadequate dietary intake, since although breastfeeding provides all nutrients and energy required by infants up to 6 months of age, it is not sufficient for children above 6 months of age.

Only a few mothers allowed their children to self-feed (children above 15 months have the psychomotor ability to feed themselves). Commonly cited reasons were lack of time to supervise the child (selffeeding can be very slow) and fear of wasting food (e.g. food is dropped to the ground).

\section{Context-specific feeding practices}

The qualitative data also revealed some context-specific complementary feeding practices.

Due to economic constraints mothers in Shiree reported that they often feed only left-over non-reheated food to their children (including older children) as they believed the children's hunger would be satisfied sooner (by cold food) and overall food consumption would be lower. This practice might result in insufficient amounts of food being consumed and may also increase the risk of bacterial food contamination (especially as cooked foods had to be stored in high environmental temperatures that promotes bacterial growth).

While complementary feeding was commonly started at 6 months of age in Shiree and UPPR, mothers in CLP often provided rice porridge or infant formula additional to breast milk before 6 months of age. The reason for this was that many mothers (encouraged by their relatives) believed that breast milk would not be enough for the growing baby. There were also some gender-specific differences with male infants being fed solid foods earlier (at around 6 months of age) and female infants receiving solid foods later (around 7 months). This practice was explained by beliefs around gender-specific characteristics ('boys have less patience') and desired behaviours ('girls need to learn to be patient').

\subsection{Maternal nutrition and food consumption}

Quantitative data show that maternal undernutrition was highly prevalent in the Shiree area with almost half of all mothers being classified as underweight (44 to 45\%), closely followed by CLP with 40\%, and by UPPR with 21 to $22 \%$ of all mothers. Maternal underweight is a major cause for intrauterine growth restriction and consequently low birth weight (LBW) (Black, Victora et al., 2013). Maternal 
overweight was negligible in Shiree and CLP, but affects 16 to $18 \%$ of mothers in the urban areas of UPPR (Table 3.3.1).

Table 3.3.1: Nutritional status of mothers in the three programme areas (based on anthropometric measurements in the quantitative baseline survey)

\begin{tabular}{|l|c|c|c|}
\hline & Shiree, (\%) & CLP, (\%) & UPPR, (\%) \\
\hline Nutrition indicator & L L+N & L L+N & L+N \\
\hline Mother (15-49 years) & & 40 & 21 to 22 \\
\hline Underweight (BMI<18.5 kg/m²) & 44 to 45 & 2 & 16 to 18 \\
\hline Overweight (BMI> $25 \mathrm{~kg} / \mathrm{m}^{2}$ & 2 & 40
\end{tabular}

$B M I=$ body mass index. The range in the table refers to the range in the percentages between $L$ and $L+N$ intervention sites.

Quantitative analysis of maternal food consumption in the 24 hours preceding data collection also revealed limited dietary diversity for mothers in all three programmes. Mothers' diets mainly consisted of cereals, white tubers and roots, and other vegetables. Consumption of animal-source foods was low and infrequent (Table 3.3.2).

Table 3.3.2: Dietary diversity in the previous day for mothers of children age 6-24 months, self-reported (based on the quantitative baseline survey)

\begin{tabular}{|l|c|c|c|}
\hline & Shiree, (\%) & CLP, (\%) & UPPR, (\%) \\
\hline Mothers' dietary diversity & $\mathbf{L} \mathbf{L}+\mathbf{N}$ & $\mathbf{L}+\mathbf{N}$ & $\mathbf{L}$ \\
\hline Consumed Cereal yesterday (\%) & 99 to 100 & 99 to 100 & 9 \\
\hline Consumed Vit A rich veg yesterday (\%) & 3 to 4 & 13 & 85 to 86 \\
\hline $\begin{array}{l}\text { Consumed White tubers/roots yesterday } \\
\text { (\%) }\end{array}$ & 71 to 72 & 73 to 75 & 40 to 42 \\
\hline Consumed Green leafy veg yesterday (\%) & 32 to 35 & 46 to 47 & 94 \\
\hline Consumed Other vegetables yesterday (\%) & 91 & 93 & 3 to 4 \\
\hline Consumed Vit A rich fruits yesterday (\%) & 2 & 3 & 20 \\
\hline Consumed Other fruits yesterday (\%) & 12 & 13 to 15 & 15 to 18 \\
\hline Consumed Meat yesterday (\%) & 4 & 8 to 8 & 19 \\
\hline Consumed Eggs yesterday (\%) & 4 to 5 & 48 to 50 & 51 to 52 \\
\hline Consumed Fish yesterday (\%) & 81 to 82 & 23 & 49 \\
\hline Consumed Beans peas lentils yesterday (\%) & 22 to 26 & 12 to 13 & 13 to 14 \\
\hline Consumed Dairy yesterday (\%) & 4 & 4.4 & 5.0 to 5.1 \\
\hline Number of groups yesterday (of 12) & 4.3 to 4.4 & & \\
\hline
\end{tabular}

The range in the table refers to the range in the percentages between $L$ and $L+N$ intervention sites.

As highlighted previously, qualitative findings indicated that poverty combined with high food and fuel prices (relative to the available household income) often determined the types and amounts of foods a household could afford. Consequently, diets were often of low quality. In addition, several women reported that they had relatively little decision-making power with regard to their daily diets as meal plans and shopping lists were developed by their mothers-in-law (or sometimes their husbands). This is common in the patriarchal society of Bangladesh (e.g. Feldman et al. 2011; Walton et al. 2012).

\section{Nutrition during pregnancy}

A nutritious and varied diet during pregnancy is particularly important to facilitate healthy development of the foetus and decrease the risk for maternal morbidity and mortality (Bhutta, Cabral et al. 2012).

In addition to the economic constraints to a healthy maternal diet, the qualitative data highlighted several social and cultural barriers. Different and often context-specific traditional customs and beliefs 
guided dietary practices during pregnancy. Many of these customs included food taboos and aversions during pregnancy (e.g. pregnant women were advised not to consume fish or seafood as these were believed to cause swelling; pineapple consumption was said to cause death of the foetus). In Shiree study communities pregnant women were encouraged not to drink much water in the afternoon to avoid leaving the house to go to the toilet during sunset, an inauspicious time of day. These food and drink taboos were deeply-rooted within the local communities and actively promoted by mother-in-laws, traditional midwives and elderly relatives even if they were in contrast with the recommendations provided by health workers. While some mothers attempted to challenge elderly womens' recommendations (especially when they were in contrast with recommendations provided by the health workers), others trusted and followed the advice from their female relatives and traditional midwives.

Another harmful practice that was described by several mothers was the deliberate restriction of food intake to avoid the baby becoming 'too large' and thereby making labour more difficult and dangerous (especially if delivery took place at home).

While many of the traditional dietary practices during pregnancy were potentially damaging to both mother and child, there were also some health-promoting customs such as the provision of an extra egg or milk to pregnant women in UPPR.

Fasting during Ramadan and dietary practices due to religious or cultural beliefs may have further effects on maternal nutrition. The qualitative team currently collects additional qualitative data on these important issues.

\section{Perceptions about physical labour during pregnancy}

While there was a general awareness that pregnant women should not engage in heavy physical labour (e.g. intensive farming activities, carrying heavy loads), several mothers and pregnant women (especially in CLP) regularly engaged in strenuous work until their $9^{\text {th }}$ month of pregnancy. Apart from the economic necessity to continue to work, the local belief that vigorous activity supports the baby's movements and 'prevents sticking to the mother's belly' were frequently mentioned as explanations. Physically demanding work during pregnancy can increase the risk for adverse birth outcomes including low birth weight (LBW) and preterm delivery significantly as shown in a recent systematic review (van Beukering, van Melick et al. 2014).

\subsection{Maternal healthcare seeking behaviours}

Quantitative data showed that while 70\% of mothers in CLP and 89\% of mothers in UPPR reported that they received some antenatal care, only 41 to $50 \%$ of mothers in Shiree did so (Table 3.4.1). Similarly, women in Shiree were less likely to have received iron supplements from their health worker during pregnancy (35 to 40\%) compared to women in CLP and UPPR (both around 68 to $70 \%$ ).

Table 3.4.1: Antenatal care for mothers of children age 6-24 months, self-reported (based on the quantitative baseline survey)

\begin{tabular}{|l|c|c|c|}
\hline & Shiree, (\%) & CLP, (\%) & \multicolumn{2}{c|}{ UPPR, (\%) } \\
\hline Mothers' antenatal care & $\mathbf{L} \mathbf{L + N}$ & $\mathbf{L} \mathbf{L + N}$ & $\mathbf{L}+\mathbf{N}$ \\
\hline Any antenatal care (\%) & 41 to 50 & 70 & 89 \\
\hline Number of antenatal visits (No.) & 2.4 & 2.7 to 2.9 & 3.8 \\
\hline Received iron supplement (\%) & 35 to 40 & 68 to 69 & 68 to 70 \\
\hline
\end{tabular}

The range in the table refers to the range in the percentages between $L$ and $L+N$ intervention sites. 
The qualitative interviews found that local NGOs in all three programme areas had actively promoted the importance of antenatal care in previous years. As a result of this the number of women who attended antenatal check-ups had increased considerably according to the community members. Nevertheless, many elderly women (especially in CLP) objected to antenatal check-ups as these were perceived to interfere with the natural process of pregnancy and child birth. Consequently, many women (especially young women) did not consult antenatal care check-ups regularly (or at all).

"During my time there was no check-up system. My child delivery happened naturally"

[IDI respondent, CLP]

"Nowadays pregnant women take vitamin tablets more so their child delivery doesn't happen normally. They need to have a C-section because the foetus grows big inside the womb".

[IDI respondent, CLP]

The quantitative survey data showed that assistance at delivery varied considerably by site. About 34 to $40 \%$ of women in Shiree and about 38 to $41 \%$ in CLP were assisted by some type of trained attendant, but the large majority of these was a trained traditional birth attendant (dali) (rather than a doctor, midwife, or nurse). A majority in both Shiree and CLP were also attended by mothers or mothers-inlaw (roughly $70 \%$ in each), and many were attended by neighbours or friends (roughly $50 \%$ in each). By contrast, in UPPR, 73 to $75 \%$ were assisted by some type of trained attendant, and of these, 42 to $45 \%$ were assisted by a doctor, 49 to $50 \%$ were assisted by a midwife or nurse, and only 22 to $26 \%$ were assisted by a trained traditional birth attendant. In UPPR, only 42 to $43 \%$ were attended by mothers or mothers in law, and 22 to $23 \%$ were attended by neighbours or friends. The patterns suggest large differences in births assisted by skilled health workers (such as doctors, midwives, or nurses) as opposed to traditional birth attendants or family and friends across rural and urban areas.

Table 3.4.2: Assistance at birth for mothers of children age 6-24 months, self-reported (based on the quantitative baseline survey)

\begin{tabular}{|c|c|c|c|}
\hline & Shiree, (\%) & CLP, (\%) & UPPR, (\%) \\
\hline Mothers' assistance at birth & L $\quad \mathbf{L}+\mathbf{N}$ & $L \quad L+N$ & L $\quad \mathbf{L}+\mathbf{N}$ \\
\hline Doctor & 5 & 5 & 42 to 45 \\
\hline Midwife or nurse & 4 to 5 & 5 & 49 to 50 \\
\hline Village doctor & 2 & 2 & 0 to 1 \\
\hline Trained traditional birth attendant & 28 to 33 & 31 to 35 & 22 to 26 \\
\hline Any trained person (any of above) & 34 to 40 & 38 to 41 & 73 to 75 \\
\hline Mother or mother-in-law & 72 to 75 & 68 to 69 & 42 to 43 \\
\hline Neighbour or friend & 49 to 56 & 43 to 45 & 22 to 23 \\
\hline
\end{tabular}

The range in the table refers to the range in the percentages between $L$ and $L+N$ intervention sites.

The qualitative data suggests various reasons for the relatively low percentage of women in Shiree and CLP who gave birth with a medically trained birth attendant and reluctance to deliver in a medical facility. These reasons included lack of trust as well as a belief that hospitals do not like to cater for the poor (e.g. belief that the health facilities tend to prefer more expensive and less time-consuming Csections, 'suck blood [money] of the poor'), fears and misinformation (e.g. in BRAC ${ }^{4}$ delivery centres

\footnotetext{
${ }^{4} \mathrm{BRAC}$ is an international development organisation based in Bangladesh. It is one of the largest NGOs in the world. BRAC is active in all districts in Bangladesh as well as in many other countries.
} 
mothers' hands and feet are bound during delivery), geographical inaccessibility (e.g. flooding, inaccessible roads) and security concerns during travel (UPPR) (e.g. being robbed). Consequently, many women continue to deliver at home and prefer and trust local midwives (Dali) (the decision to deliver at home is also often influenced by the husband and mother-in-law). Institutional delivery, the presence of medically trained birth attendant and regular antenatal check-ups can significantly reduce the risk of neonatal mortality, birth complications and maternal mortality significantly (WHO 2006, WHO 2006).

\subsection{Summary matrix of quantitative and qualitative key findings on nutrition}

In table 3.5.1 quantitative and qualitative baseline findings on nutrition were juxtaposed in a summary matrix. Potential impacts on the effectiveness of the nutrition intervention and issues to follow up in end line data collection are presented in column 4 and 5 of the matrix.

\begin{tabular}{|c|c|c|c|c|}
\hline & $\begin{array}{l}\text { Quantitative } \\
\text { baseline }\end{array}$ & $\begin{array}{l}\text { Qualitative } \\
\text { fieldwork }\end{array}$ & $\begin{array}{c}\text { Potential pathways } \\
\text { for nutrition } \\
\text { intervention }\end{array}$ & $\begin{array}{c}\text { To address in next } \\
\text { quant \& qual data } \\
\text { collection }\end{array}$ \\
\hline $\begin{array}{l}\text { Manifestation } \\
\text { of child } \\
\text { undernutrition }\end{array}$ & $\begin{array}{l}\text { Medium to very } \\
\text { high levels of child } \\
\text { undernutrition } \\
\text { across three } \\
\text { programme sites } \\
\text { (lowest } \\
\text { malnutrition in } \\
\text { UPPR, highest in } \\
\text { Shiree) }\end{array}$ & $\begin{array}{l}\text { Child undernutrition } \\
\text { is not perceived as a } \\
\text { priority, but link to } \\
\text { poor health and } \\
\text { ability to work is } \\
\text { highlighted }\end{array}$ & $\begin{array}{l}\text { Raised awareness of } \\
\text { undernutrition and } \\
\text { its multiple } \\
\text { consequences } \\
\text { (including on future } \\
\text { health and } \\
\text { economic well- } \\
\text { being) may facilitate } \\
\text { a change in attitude } \\
\text { and behaviour } \\
\text { towards } \\
\text { undernutrition }\end{array}$ & $\begin{array}{l}\text { Has the prevalence } \\
\text { of child } \\
\text { undernutrition } \\
\text { decreased? } \\
\text { Has the } \\
\text { community's } \\
\text { awareness and } \\
\text { perceptions of } \\
\text { undernutrition } \\
\text { changed? } \\
\text { How? Why? }\end{array}$ \\
\hline $\begin{array}{l}\text { Child nutrition } \\
\text { Breastfeeding }\end{array}$ & $\begin{array}{l}\text { Majority of mothers } \\
\text { (80-90\%) know } \\
\text { about appropriate } \\
\text { breastfeeding } \\
\text { practices (similar } \\
\text { across three sites) }\end{array}$ & $\begin{array}{l}\text { Breastfeeding } \\
\text { almost universal in } \\
\text { first } 6 \text { months } \\
\text { Prelactael feeding is } \\
\text { widely practiced } \\
\text { and culturally } \\
\text { supported } \\
\text { High prevalence of } \\
\text { home delivery } \\
\text { encourages } \\
\text { prelactael practices } \\
\text { and prevents } \\
\text { facility-based } \\
\text { breastfeeding } \\
\text { promotion from } \\
\text { reaching mothers }\end{array}$ & $\begin{array}{l}\text { Improvement of } \\
\text { timely initiation of } \\
\text { breastfeeding and } \\
\text { discouragement of } \\
\text { prelactael feeding } \\
\text { may optimise } \\
\text { breastfeeding } \\
\text { practice further } \\
\text { Prelactael feeding } \\
\text { may continue as } \\
\text { relatives and other } \\
\text { community } \\
\text { members have } \\
\text { immediate access } \\
\text { to /care of the } \\
\text { new-born and lack } \\
\text { of awareness }\end{array}$ & $\begin{array}{l}\text { Has attitude } \\
\text { towards the } \\
\text { practice of } \\
\text { prelactael feeding } \\
\text { changed? Whose } \\
\text { behaviour has } \\
\text { changed and why? }\end{array}$ \\
\hline
\end{tabular}




\begin{tabular}{|c|c|c|c|c|}
\hline $\begin{array}{l}\text { Child nutrition } \\
\text { Complementary } \\
\text { feeding }\end{array}$ & $\begin{array}{l}\text { Majority of mothers } \\
\text { (50-75\%) know } \\
\text { about age- } \\
\text { appropriate } \\
\text { complementary } \\
\text { feeding practices } \\
\text { (most knowledge in } \\
\text { UPPR, least in } \\
\text { Shiree) } \\
\text { Low diversity of } \\
\text { complementary } \\
\text { foods, mainly } \\
\text { starchy foods (most } \\
\text { diverse in UPPR, } \\
\text { least in Shiree) }\end{array}$ & $\begin{array}{l}\text { Good awareness of } \\
\text { what constitutes a } \\
\text { nutritious diet } \\
\text { Multiple reasons for } \\
\text { sub-optimal } \\
\text { complementary } \\
\text { feeding practices } \\
\text { including lack of } \\
\text { money to purchase } \\
\text { diverse foods and } \\
\text { cooking fuel, limited } \\
\text { geographical } \\
\text { accessibility to fresh } \\
\text { foods, lack of time } \\
\text { for responsive } \\
\text { feeding, lack of } \\
\text { awareness of what } \\
\text { constitutes age- } \\
\text { appropriate foods } \\
\text { (with regards to } \\
\text { consistency, } \\
\text { amounts, types), } \\
\text { differing beliefs } \\
\text { around timings of } \\
\text { the introduction of } \\
\text { solid foods }\end{array}$ & $\begin{array}{l}\text { Economic, social } \\
\text { and geographical } \\
\text { factors may hinder } \\
\text { mothers' attempts } \\
\text { to establish } \\
\text { adequate } \\
\text { complementary } \\
\text { feeding practices } \\
\text { despite raised } \\
\text { awareness and } \\
\text { knowledge }\end{array}$ & $\begin{array}{l}\text { Has the dietary } \\
\text { diversity of } \\
\text { complementary } \\
\text { foods changed? } \\
\text { Has awareness } \\
\text { about age- } \\
\text { appropriate feeding } \\
\text { practices changed? } \\
\text { How have mothers } \\
\text { addressed the } \\
\text { different barriers to } \\
\text { adequate } \\
\text { complementary } \\
\text { feeding? Which } \\
\text { challenges persist } \\
\text { and why? }\end{array}$ \\
\hline $\begin{array}{l}\text { Maternal } \\
\text { nutrition }\end{array}$ & $\begin{array}{l}\text { Prevalence of } \\
\text { maternal } \\
\text { underweight varies } \\
\text { by site (fewest } \\
\text { underweight in } \\
\text { UPPR, most in } \\
\text { Shiree) } \\
\text { Prevalence of } \\
\text { overweight varies } \\
\text { by site (most } \\
\text { overweight in UPPR, } \\
\text { negligible in CLP } \\
\text { and Shiree) } \\
\text { Low dietary } \\
\text { diversity of } \\
\text { maternal diets }\end{array}$ & $\begin{array}{l}\text { Economic, social, } \\
\text { geographical and } \\
\text { cultural constraints } \\
\text { to a varied and } \\
\text { healthy diet } \\
\text { Deeply-rooted food } \\
\text { taboos and } \\
\text { behaviours during } \\
\text { pregnancy that are } \\
\text { promoted by } \\
\text { mothers-in-law and } \\
\text { elderly and often } \\
\text { contrast with health } \\
\text { workers' } \\
\text { recommendations } \\
\text { Some traditional } \\
\text { food taboos in } \\
\text { pregnancy can be } \\
\text { harmful for the } \\
\text { mother and the } \\
\text { child; others can be } \\
\text { beneficial }\end{array}$ & $\begin{array}{l}\text { Multiple barriers } \\
\text { may hinder up-take } \\
\text { of a nutritious } \\
\text { maternal diet } \\
\text { Mothers-in-law and } \\
\text { elderly may } \\
\text { continue to } \\
\text { promote harmful } \\
\text { practices and hinder } \\
\text { behaviour change } \\
\text { to support a healthy } \\
\text { pregnancy }\end{array}$ & $\begin{array}{l}\text { Has the prevalence } \\
\text { of maternal } \\
\text { underweight } \\
\text { change? } \\
\text { How have mothers/ } \\
\text { other household } \\
\text { members addressed } \\
\text { the different } \\
\text { barriers to better } \\
\text { nutrition? Which } \\
\text { challenges persist } \\
\text { and why? } \\
\text { Have traditional } \\
\text { practices during } \\
\text { pregnancy } \\
\text { changed? } \\
\text { What role did } \\
\text { mothers-in-law and } \\
\text { elderly play? }\end{array}$ \\
\hline $\begin{array}{l}\text { Maternal } \\
\text { healthcare } \\
\text { seeking }\end{array}$ & $\begin{array}{l}\text { Large majority } \\
\text { received some } \\
\text { antenatal care in } \\
\text { UPPR and CLP, } \\
\text { fewer in Shiree }\end{array}$ & $\begin{array}{l}\text { Antenatal care use } \\
\text { has increased in } \\
\text { recent years due to } \\
\text { the promotion of its } \\
\text { benefits by local } \\
\text { NGOs }\end{array}$ & $\begin{array}{l}\text { Multiple cultural, } \\
\text { social and } \\
\text { geographical } \\
\text { barriers may hinder } \\
\text { up-take of } \\
\text { antenatal care and }\end{array}$ & $\begin{array}{l}\text { Has women's } \\
\text { attitude towards } \\
\text { antenatal care and } \\
\text { institutional } \\
\text { delivery changed? } \\
\text { How and why? }\end{array}$ \\
\hline
\end{tabular}




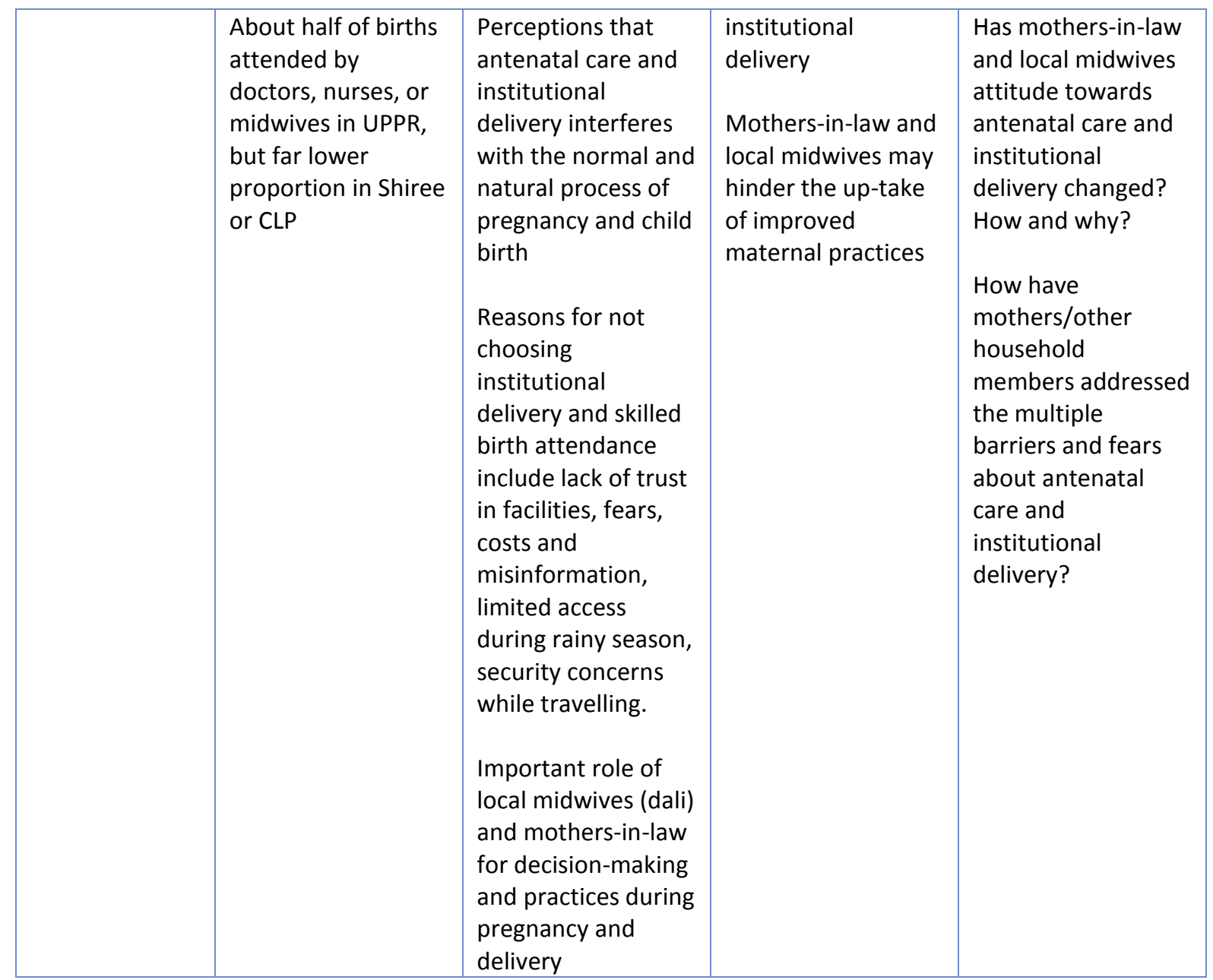

\section{The social, economic, political and cultural context of the 3 programmes}

This section combines quantitative and qualitative baseline findings on the social, economic, governance and environmental context at baseline. The focus is on contextual factors that may affect children's nutritional status directly or indirectly and on factors that may influence the up-take and effectiveness of the nutrition interventions.

\subsection{Access to water and sanitation and hygiene practices}

Unsafe drinking water, lack of adequate sanitation and poor hygiene practices are a major cause for childhood morbidity and mortality (Chambers, von Medeazza 2014, Prüss, Kay et al. 2002, Cairncross, Hunt et al. 2010), growth faltering and poor nutritional outcomes among children (Fewtrell, Kaufmann et al. 2005, Dangour, Watson et al. 2013).

\section{Access to safe drinking water}

The qualitative team found that waterborne diseases including diarrhoea and vomiting are common health concerns for young children in all study sites. Quantitative data showed that nearly all households have access to safe drinking water in all three sites (Table 4.1.1). 
Table 4.1.1: Hygiene and sanitation in the home, self-reported (based on the quantitative baseline survey)

\begin{tabular}{|l|c|c|c|}
\hline & Shiree, (\%) & CLP, (\%) & UPPR, (\%) \\
\hline Water and sanitation & $\mathbf{L} \mathbf{L + N}$ & $\mathbf{L} \mathbf{L + N}$ & $\mathbf{L}+\mathbf{N}$ \\
\hline Access to safe drinking water & 96 & 99 & 99 \\
\hline Access to sanitary latrine & 8 to 10 & 35 & 50 to 57 \\
\hline
\end{tabular}

The range in the table refers to the range in the percentages between $L$ and $L+N$ intervention sites.

However, qualitative data suggests that while most households had access, actual use of safe water varied greatly between the dry and the rainy season (which can last 5 months or longer). During the dry seasons households suffered frequent water shortages. During the rainy seasons flooding often restricted households' movements and access to safe drinking water for long periods of time. Several community members in all three programmes described how they had to use surface water from ponds or rivers for household consumption. While several mothers were aware of the need to boil surface water for safe consumption, high cooking fuel prices and lack of time often prevented this.

In both Shiree and UPPR access to safe drinking water was in several cases controlled by local elites and influential community members. In one L+N study communities of Shiree, communal tube wells were located at the houses of influential people who took control over the access to water and could also restrict it. In UPPR 3-4 households shared a water pipe which usually supplied drinking water for a short period of time every day. During this period the owner of the house with the pipe collected water and then sold it to the other households. This frequently led to conflicts if the holder of the water pipe decided to increase water prices or the water buyers did not have sufficient money to pay for it.

\section{Access to adequate sanitation}

Access to adequate sanitation varied considerably across the three programme areas (Table 3.1.1). Only 8 to $10 \%$ of households reported access to a sanitary latrine in Shiree, while 35\% reported access in CLP, and 50 to $57 \%$ reported access in UPPR.

The qualitative data extends these findings by highlighting that even if a household reported access to improved sanitation, facilities often had to be shared with other households. This frequently led to dissatisfaction and conflict because of poor maintenance and cleanliness of the shared facilities, lack of privacy, security concerns of females and the use of the facility for other purposes (e.g. storage facility). Open defecation, especially among children, was therefore common and often preferred.

In all three programmes, latrines were often unusable during the rainy season due to overflow and flooding. Similarly during the dry season the acute water shortage often made it difficult to keep latrines clean.

\section{Hygiene practices}

Mothers and adolescent girls in all three sites had some knowledge about when to wash their hands (Table 4.1.2). On average, both mothers and adolescent girls could identify at least two instances in which hand washing would be appropriate. Mothers were able to report more on average than adolescent girls, and respondents in UPPR and CLP were able to report more than those in Shiree. 
Table 4.1.2: Knowledge of hand washing, mothers and adolescent girls (based on the quantitative baseline survey)

\begin{tabular}{|l|c|c|c|}
\hline & Shiree, (\%) & CLP, (\%) & UPPR, (\%) \\
\hline Hygiene & $\mathbf{L ~ L + N}$ & $\mathbf{L} \mathbf{L}+\mathbf{N}$ & $\mathbf{L}+\mathbf{N}$ \\
\hline $\begin{array}{l}\text { Number of answers given on when } \\
\text { to wash hands, mothers }\end{array}$ & 2.2 to 2.3 & 2.5 & 2.5 to 2.6 \\
\hline $\begin{array}{l}\text { Number of answers given on when } \\
\text { to wash hands, adolescent girls }\end{array}$ & 2.0 to 2.1 & 2.3 to 2.4 & 2.3 to 2.4 \\
\hline
\end{tabular}

The range in the table refers to the range in the percentages between $L$ and $L+N$ intervention sites.

During the qualitative fieldwork, community members felt that overall hygiene behaviours had improved as a result of previous hygiene interventions by local NGOs and health workers. However, knowledge and access to facilities did not automatically ensure better hygiene behaviour. Several households reported that it was difficult to keep up hand washing practices and other hygienic behaviours during the rainy season and in times of acute water shortage. Lack of soap and no visible dirt on the hands were commonly cited reasons for insufficient hand washing practices.

Demographic and socioeconomic characteristics of some households may have contributed to poor hygiene and sanitation (Table 4.1.3). Shiree households had dependency ratios ${ }^{5}$ of 1.4 to 1.5 on average, denoting 40-50\% more "dependents" in the household than individuals of "working age" (ages 15-64) and implying limited resources to be shared over these dependents. This may be linked to less resources and awareness of good hygiene practices (as well as other child care practices).

Table 4.1.3: Demographic and socioeconomic conditions (based on the quantitative baseline survey)

\begin{tabular}{|l|c|c|c|}
\hline & Shiree, (\%) & CLP, (\%) & UPPR, (\%) \\
\hline $\begin{array}{l}\text { Demographic and socioeconomic } \\
\text { conditions }\end{array}$ & $\mathbf{L} \mathbf{L + N}$ & $\mathbf{L} \mathbf{L + N}$ & $\mathbf{L}+\mathbf{N}$ \\
\hline Dependency ratio & 1.4 to 1.5 & 1.1 & 0.8 to 0.9 \\
\hline Head's years of schooling & 0.9 to 1.0 & 1.3 to 1.6 & 3.4 to 3.5 \\
\hline $\begin{array}{l}\text { Child's mother's/caregiver's years of } \\
\text { schooling }\end{array}$ & 1.2 to 1.4 & 2.1 to 2.3 & 4.6 to 5.1 \\
\hline Dirt floor (\%) & 100 & 100 & 56 to 58 \\
\hline Tin wall (\%) & 55 to 56 & 54 & 40 to 43 \\
\hline Other non-permanent wall (\%) & 43 & 46 & 18 to 19 \\
\hline Tin roof (\%) & 93 to 94 & 95 & 91 \\
\hline Other non-permanent roof (\%) & 5 to 6 & 4 & 91 \\
\hline Access to electricity (\%) & 9 to 16 & 4 & 3 \\
\hline
\end{tabular}

The range in the table refers to the range in the percentages between $L$ and $L+N$ intervention sites

Unhygienic living conditions such a crowed living spaces (in UPPR), poor housing conditions, open sewage systems (UPPR), lack of safe garbage disposal, overrun latrines (Shiree and CLP) and frequent flooding that was often combined with insufficient or lacking drainage (in the study communities of all three areas) posed additional challenges for child health and nutrition.

\footnotetext{
${ }^{5}$ Dependency ratio: Age-population ration of those household members not in the labour force (dependent) and those in the labour force.
} 


\subsection{Vulnerability to climatic events and effects on child health and nutrition}

Qualitative data found that households in the study communities of all three areas experienced annual climatic events (i.e. flooding, heavy rain falls and drought). Quantitative data highlighted that the three areas varied with regards to the impact of climatic events (Table 4.2.1). CLP households were most vulnerable to losing valuables (e.g. home and assets) in river erosion or floods, while Shiree households were vulnerable to losing valuables in floods or storms/drought. Few UPPR households reported loss of valuables due to climatic events.

Table 4.2.1: Loss of home and assets due to climatic events (based on the quantitative baseline survey)

\begin{tabular}{|l|c|c|c|}
\hline & Shiree, (\%) & CLP, (\%) & UPPR, (\%) \\
\hline Exposure to climatic events & $\mathbf{L} \mathbf{L + N}$ & $\mathbf{L} \mathbf{L + N}$ & $\mathbf{L}+\mathbf{N}$ \\
\hline $\begin{array}{l}\text { Loss of home to river erosion, last } 5 \\
\text { yrs }\end{array}$ & 1 & 11 to 12 & 0.5 \\
\hline $\begin{array}{l}\text { Loss of crops/assets to floods, last } 5 \\
\text { yrs }\end{array}$ & 5 & 14 & 1 to 2 \\
\hline $\begin{array}{l}\text { Loss of crops/assets to } \\
\text { storms/drought/theft, last 5 yrs }\end{array}$ & 7 to 8 & 4 & L \\
\hline
\end{tabular}

The range in the table refers to the range in the percentages between $L$ and $L+N$ intervention sites

To counteract the consequences of climatic events households employed different coping strategies including preventive measures (e.g. building up food storage as protection from flooding, use of sand bags, raising plinths) and measures to deal with loss of assets and homes (e.g. drawing on social networks for help, taking up loans, selling assets).

Nevertheless, negative impacts of flooding on livelihoods, health and nutrition often could not be prevented. In this context several households described how the severity of annual flooding and droughts seem to have worsened during the last decade perhaps due to climate change. There are some site-specific characteristics with regards to the vulnerability to climatic events:

\section{Climatic vulnerability in Shiree}

The haor basin in Shiree experiences severe flooding for 6 to 8 months each year. Consequent loss of crops and assets was reported by 5\% of households. Similar to the findings from the CLP area, qualitative data illustrated a curtailing of mobility, worsening of hygienic and sanitary condition and decrease of household food security (especially in haor areas where homestead gardening for household consumption was impossible) due to the increase in flooding.

\section{Climatic vulnerability in CLP}

According to the survey 11 to $12 \%$ of all households in CLP had been affected by severe river erosion in the last 5 years and 14\% reported that they lost crops or other livelihood assets as a result of flooding. Riverbank erosion also often resulted in a loss of shelter and human lives. During the qualitative interviews community members highlighted other consequences of the flooding including disruptions of transport systems that restricted mobility and posed significant barriers to the access to healthcare, antenatal care, education and food markets (to sell products produced by the household and purchase fresh vegetables and fruits for a varied diet). Flooding also restricted access to safe drinking water and sanitation and worsened hygienic conditions. Unsurprisingly, mothers described a steep increase in the incidence of ill health (e.g. diarrhoea, fever) among children and other family members in times of flooding. Food insecurity also typically increased during this time because of limited access to markets, income and lack of safe storage of food items. 


\section{Climatic vulnerability in UPPR}

While only very little evidence for an impact of climatic shocks on livelihoods in UPPR was found in the quantitative data, the qualitative data highlighted several negative consequences of heavy monsoon rains on living conditions in crowded, poorly-drained and often flood-prone slum areas. Overflow of sewage systems and garbage disposal sides combined with often inadequate housing frequently increased the incidences of waterborne diseases as well as the transmission and spreading of diseases. In some hilly areas of UPPR landslides were common and could result in lost lives and livelihoods and blocked transport roads (e.g. access to income-generating opportunities and labour markets, health facilities, food markets was disrupted).

\section{Impact of climatic events on livelihoods in the three programme areas}

The loss of assets, livelihoods and income-generating opportunities due to climatic events and the parallel increase in ill-health often had long-lasting negative effects on already poor households. Stable incomes and job-related benefits (e.g. sick pay) were rare among the study population in the three programme areas and the majority of men reported to work as daily labours or to be self-employed (e.g. rickshaw puller, petty traders) in the quantitative survey. While half or more of the women in Shiree and CLP contributed to the household income generation (in cash or kind), female job participation in UPPR was low (68\% of women did not work) and households often had to rely on sole incomes.

\subsection{Intra-household decision-making and women status}

In the quantitative survey, the majority of mothers in Shiree, CLP and UPPR areas report that decisions about food purchases, healthcare, and education were made jointly by themselves and their husbands (Table 4.3.1). The proportion of women reporting that they themselves control income needed to buy food at the market varies by site, with 53 to $56 \%$ reporting that they do in UPPR sites, $48 \%$ reporting that they do in Shiree sites, and only 35 to $37 \%$ reporting that they do in CLP sites. 
Table 4.3.1: Mothers' say/participation in intra-household decision-making, self-reported (based on the quantitative baseline survey)

\begin{tabular}{|c|c|c|c|}
\hline \multirow{2}{*}{$\begin{array}{l}\text { Who decides how to spend money } \\
\text { on...? }\end{array}$} & Shiree, (\%) & CLP, (\%) & UPPR, (\%) \\
\hline & $L \quad L+N$ & $L \quad L+N$ & $\mathbf{L} \quad \mathbf{L}+\mathbf{N}$ \\
\hline \multicolumn{4}{|l|}{ Food } \\
\hline Yourself & 12 to 13 & 8 to 10 & 9 to 10 \\
\hline Your husband & 27 to 30 & 27 to 29 & 21 to 23 \\
\hline Self and husband & 53 to 57 & 59 to 60 & 50 to 52 \\
\hline Someone else & 4 & 3 to 4 & 16 to 19 \\
\hline \multicolumn{4}{|l|}{ Healthcare } \\
\hline Yourself & 13 to 14 & 7 to 10 & 9 to 10 \\
\hline Your husband & 22 to 29 & 24 to 25 & 18 to 21 \\
\hline Self and husband & 55 to 61 & 63 to 64 & 56 to 57 \\
\hline Someone else & 3 to 4 & 3 to 4 & 14 to 17 \\
\hline \multicolumn{4}{|l|}{ Education } \\
\hline Yourself & 10 & 3 to 6 & 6 to 7 \\
\hline Your husband & 16 to 21 & 14 to 15 & 12 to 15 \\
\hline Self and husband & 41 to 45 & 37 to 38 & 38 to 39 \\
\hline Someone else & 2 to 3 & 2 to 3 & 10 to 14 \\
\hline \multicolumn{4}{|l|}{$\begin{array}{l}\text { Do you control income needed to } \\
\text { buy food at the market? }\end{array}$} \\
\hline Yes & 48 & 35 to 37 & 53 to 56 \\
\hline
\end{tabular}

The range in the table refers to the range in the percentages between $L$ and $L+N$ intervention sites

Despite the high proportion of joint decision-making, less than half of the women in Shiree and CLP and only slightly more than $50 \%$ of women in UPPR controlled the money needed for food purchases. Women also perceived themselves to have only limited power and control over their lives according to the survey (Table 4.3.2).

Table 4.3.2: Mothers' Women's perceived power and control over their lives, self-reported (based on the quantitative baseline survey)

\begin{tabular}{|c|c|c|c|}
\hline & Shiree, (\%) & CLP, (\%) & UPPR, (\%) \\
\hline $\begin{array}{l}\text { Women's perceived power and } \\
\text { control }\end{array}$ & $L \quad L+N$ & L $\quad \mathbf{L}+\mathbf{N}$ & $\mathbf{L} \quad \mathbf{L}+\mathbf{N}$ \\
\hline $\begin{array}{l}\text { Women's perceived position on a 9- } \\
\text { step "power" ladder (people on Step } \\
1 \text { are completely without rights, } \\
\text { people on Step } 9 \text { have a lot of } \\
\text { power) }\end{array}$ & 2.31 to 2.24 & 2.43 to 2.57 & 2.69 to 2.73 \\
\hline $\begin{array}{l}\text { Women's perceived position on a 9- } \\
\text { step "control" ladder (people on Step } \\
1 \text { are totally unable to change their } \\
\text { lives, people on Step } 9 \text { have full } \\
\text { control over their own lives) }\end{array}$ & 2.54 to 2.69 & 2.85 to 2.97 & 3.02 to 3.03 \\
\hline
\end{tabular}

The range in the table refers to the range in the percentages between $L$ and $L+N$ intervention sites

One potential explanation for why women may feel powerless and without control over their lives might lie in their daily experiences of extreme poverty and associated exclusions that emerged in the qualitative research. The following quote describes the desperation and the trade-offs an extremely poor mother had to make in order to deal with her household's situation: 
"What good things will happen by going to school? It will be better for our family to work rather than going to school. We do not have money to buy rice [the minimum food available]. So we had to give our children to bonded labour from childhood."

\section{[Mother, CLP]}

Intra-household decision-making and in particular the role of mother-in-laws and elderly community members (especially with regards to decisions about child care and nutrition) also affected women's sense of powerless and lack of control. In patriarchal Bangladesh, women traditionally move into the households of their husbands after marriage. Many young mothers in rural areas described the influence elderly relatives had on their decisions. One mother in CLP described how she always consulted her husband's mother before she made any decisions, for example with regards to family planning. The influence of the mothers-in-law was particularly pronounced in joint households (versus nuclear families that only made up a small percentage of the sample). Social pressure to comply with the advice and recommendations of the elderly was high and often deeply rooted in the mind-sets of young women, even if the advice was in conflict with recommendations of health professionals or NGO workers.

Many poor households in CLP and Shiree relied on seasonal migration of men for employment in Dhaka or other cities while women and children usually remained in the villages. The temporary absence of men and male household heads often had considerable effects on the women's status within the household and their agency, decision-making power and mobility. During these time periods women either became temporary household heads and were responsible for decision-making processes within the household, or (in case young women lived in joint households) had to sub-ordinate to other relatives of their husbands.

\subsection{Summary matrix of quantitative and qualitative findings on the context in the three programmes}

Table 4.4.1 shows the key findings from the integration of quantitative and qualitative data on the context of the three programmes. Potential influences that may hinder or promote the up-take of the nutrition interventions are also highlighted. 
Table 4.4.1: Mixed method matrix on the context of the three livelihood programmes

\begin{tabular}{|c|c|c|c|c|}
\hline & $\begin{array}{l}\text { Quantitative } \\
\text { baseline }\end{array}$ & Qualitative fieldwork & $\begin{array}{l}\text { Potential influence } \\
\text { on the nutrition } \\
\text { intervention }\end{array}$ & $\begin{array}{c}\text { To address in next } \\
\text { quant \& qual data } \\
\text { collection }\end{array}$ \\
\hline $\begin{array}{l}\text { Water, } \\
\text { sanitation and } \\
\text { hygiene } \\
\text { practices } \\
\text { Water }\end{array}$ & $\begin{array}{l}\text { Nearly universal } \\
\text { access to safe } \\
\text { drinking water }\end{array}$ & $\begin{array}{l}\text { Seasonal variation in } \\
\text { access to safe drinking } \\
\text { water, especially during } \\
\text { rainy season and } \\
\text { flooding (which can take } \\
\text { up to } 8 \text { months in Shiree } \\
\text { and several months in } \\
\text { the Chars). Households } \\
\text { use unsafe water from } \\
\text { rivers and ponds during } \\
\text { this time. } \\
\text { Economic constraints } \\
\text { and lack of time } \\
\text { prevents boiling of } \\
\text { unsafe water sources } \\
\text { Local power structures } \\
\text { control and restrict } \\
\text { access to safe water in } \\
\text { some locations }\end{array}$ & $\begin{array}{l}\text { Seasonal variation } \\
\text { in access and } \\
\text { availability of safe } \\
\text { water may lead to } \\
\text { ill health and poor } \\
\text { nutrition outcomes } \\
\text { Economic and } \\
\text { social barriers to } \\
\text { water purification } \\
\text { may prevent } \\
\text { consumption of } \\
\text { safe water in some } \\
\text { seasons } \\
\text { Inequalities and } \\
\text { exclusions in access } \\
\text { to safe drinking } \\
\text { water may force } \\
\text { households to } \\
\text { continue to } \\
\text { consume unsafe } \\
\text { water }\end{array}$ & $\begin{array}{l}\text { Has the } \\
\text { consumption of } \\
\text { unsafe water } \\
\text { changed? } \\
\text { How have } \\
\text { households } \\
\text { addressed } \\
\text { barriers to the } \\
\text { access of safe } \\
\text { drinking water } \\
\text { access in all } \\
\text { seasons? }\end{array}$ \\
\hline $\begin{array}{l}\text { Water, } \\
\text { sanitation and } \\
\text { hygiene } \\
\text { practices } \\
\text { Sanitation }\end{array}$ & $\begin{array}{l}\text { Small } \\
\text { proportion (8 to } \\
10 \% \text { ) with } \\
\text { access to } \\
\text { sanitary latrines } \\
\text { in Shiree, } \\
\text { slightly higher } \\
\text { share (35\%) } \\
\text { with access in } \\
\text { CLP, about half } \\
\text { (50 to } 57 \% \text { ) with } \\
\text { access in UPPR }\end{array}$ & $\begin{array}{l}\text { Frequent sharing of } \\
\text { sanitation facilities } \\
\text { among households is } \\
\text { necessary and often } \\
\text { results in conflict and } \\
\text { dissatisfaction due to } \\
\text { poor maintenance, lack } \\
\text { of cleanliness and } \\
\text { privacy, security } \\
\text { concerns of females and } \\
\text { use of facilities for other } \\
\text { purposes (e.g. storage) } \\
\text { Open defecation is } \\
\text { often practiced and } \\
\text { preferred } \\
\text { Latrines are often } \\
\text { unusable during rainy } \\
\text { season due to overflow }\end{array}$ & $\begin{array}{l}\text { Continued sharing } \\
\text { of sanitation } \\
\text { facilities and } \\
\text { associated } \\
\text { challenges may } \\
\text { hinder up-take of } \\
\text { safe sanitary } \\
\text { behaviours, health } \\
\text { risks associated } \\
\text { with poor practices } \\
\text { persist } \\
\text { Effects of flooding } \\
\text { and overflow may } \\
\text { continue to prevent } \\
\text { use of safe sanitary } \\
\text { facilities }\end{array}$ & $\begin{array}{l}\text { Have practices of } \\
\text { sharing of } \\
\text { sanitation } \\
\text { facilities changed } \\
\text { or were } \\
\text { challenges } \\
\text { associated with } \\
\text { sharing } \\
\text { addressed? How? }\end{array}$ \\
\hline
\end{tabular}




\begin{tabular}{|c|c|c|c|c|}
\hline $\begin{array}{l}\text { Water, } \\
\text { sanitation and } \\
\text { hygiene } \\
\text { practices } \\
\text { Hygiene } \\
\text { practices }\end{array}$ & $\begin{array}{l}\text { Knowledge of at } \\
\text { least two } \\
\text { instances when } \\
\text { to wash hands } \\
\text { among mothers } \\
\text { and adolescent } \\
\text { girls (lowest } \\
\text { knowledge in } \\
\text { Shiree, highest } \\
\text { knowledge in } \\
\text { UPPR) } \\
\\
\text { Poor living } \\
\text { conditions with } \\
\text { dirt floors and } \\
\text { low SES }\end{array}$ & $\begin{array}{l}\text { Hand washing and other } \\
\text { hygiene practices are } \\
\text { difficult to maintain } \\
\text { during rainy seasons } \\
\text { and in acute water } \\
\text { shortage } \\
\text { Unhygienic living } \\
\text { environments (open } \\
\text { sewage, unsafe garbage } \\
\text { disposal, poor housing) } \\
\text { pose barriers to hygiene } \\
\text { behaviours and risk } \\
\text { factors for child health }\end{array}$ & $\begin{array}{l}\text { Seasonal challenges } \\
\text { to hygienic } \\
\text { behaviours persist } \\
\text { and thus does } \\
\text { increase in ill health } \\
\text { during flooding and } \\
\text { rainy season } \\
\text { Poor living } \\
\text { conditions may } \\
\text { reduce the impact } \\
\text { of behaviour } \\
\text { change } \\
\text { interventions and } \\
\text { deworming }\end{array}$ & $\begin{array}{l}\text { Have hygienic } \\
\text { conditions in } \\
\text { living } \\
\text { environments } \\
\text { changes? How? } \\
\text { Why? }\end{array}$ \\
\hline Climatic events & $\begin{array}{l}\text { Reported } \\
\text { vulnerability to } \\
\text { loss of valuables } \\
\text { due to flooding } \\
\text { and } \\
\text { storms/drought } \\
\text { in CLP and } \\
\text { Shiree } \\
\text { No reported } \\
\text { vulnerability to } \\
\text { loss of valuables } \\
\text { due to climatic } \\
\text { events in UPPR }\end{array}$ & $\begin{array}{l}\text { Multiple and interlinked } \\
\text { consequences of } \\
\text { flooding on child health } \\
\text { and nutrition, access to } \\
\text { services, food security } \\
\text { and livelihoods } \\
\text { Multiple impacts of } \\
\text { annual monsoons on } \\
\text { crowded urban living } \\
\text { conditions on child } \\
\text { health and nutrition, } \\
\text { livelihoods, access to } \\
\text { employment and } \\
\text { services }\end{array}$ & $\begin{array}{l}\text { Negative } \\
\text { consequences of } \\
\text { annual } \\
\text { flooding/monsoon } \\
\text { on livelihoods, food } \\
\text { security and ill } \\
\text { health continue to } \\
\text { impair child health } \\
\text { and nutrition }\end{array}$ & $\begin{array}{l}\text { Have new coping } \\
\text { strategies with } \\
\text { climatic events } \\
\text { been developed } \\
\text { or brought in from } \\
\text { the outside? }\end{array}$ \\
\hline
\end{tabular}




\begin{tabular}{|c|c|c|c|c|}
\hline $\begin{array}{l}\text { Intra-household } \\
\text { decision-making } \\
\text { and women } \\
\text { status }\end{array}$ & $\begin{array}{l}\text { Most mothers } \\
\text { report joint } \\
\text { decision-making } \\
\text { with husbands } \\
\text { on food } \\
\text { purchase, } \\
\text { healthcare, and } \\
\text { education in all } \\
\text { three sites } \\
\text { Varying rates of } \\
\text { mothers } \\
\text { reporting } \\
\text { control over } \\
\text { income needed } \\
\text { to purchase } \\
\text { food (highest } \\
\text { control in UPPR, } \\
\text { lowest control } \\
\text { in CLP) } \\
\text { Low (2-3 out of } \\
\text { 9) perceived } \\
\text { power and } \\
\text { control among } \\
\text { mothers (lowest } \\
\text { in Shiree, } \\
\text { highest in UPPR) }\end{array}$ & $\begin{array}{l}\text { Additional influence of } \\
\text { mothers-in-laws and } \\
\text { other household } \\
\text { members on decision- } \\
\text { making } \\
\text { Extreme poverty and } \\
\text { necessary trade-offs } \\
\text { may increase the feeling } \\
\text { of powerlessness } \\
\text { Long absences of } \\
\text { husbands for work (CLP, } \\
\text { fishing communities in } \\
\text { UPR) may change intra- } \\
\text { household decision- } \\
\text { making processes }\end{array}$ & $\begin{array}{l}\text { Mothers-in-law, } \\
\text { elderly and } \\
\text { husbands may } \\
\text { hinder better } \\
\text { decision-making on } \\
\text { child health and } \\
\text { nutrition because } \\
\text { of cultural beliefs or } \\
\text { economic concerns }\end{array}$ & $\begin{array}{l}\text { Have intra- } \\
\text { household } \\
\text { decision-making } \\
\text { processes on child } \\
\text { health and } \\
\text { nutrition } \\
\text { changed? How } \\
\text { and why? }\end{array}$ \\
\hline
\end{tabular}

\section{Initial qualitative insights into the micro-dynamics of the nutrition intervention}

Table 5.1 summarises the key features, beneficiaries' initial attitude and observed challenges of the nutrition interventions nested within the three livelihood programmes. The table draws on the findings from the qualitative and quantitative work and the literature reviews conducted to inform this impact evaluation. All programmes received the same guidance and manual for the intervention. Nevertheless, some context-specific differences in the implementation (e.g. frequency and type of support provided) could be observed and are described here. However as the nutrition interventions had just been rolled out at the time of the first qualitative data collection, these observations should be interpreted with care and await analysis and conclusions from the Process Evaluation. The table also maps out other nutrition and health interventions and programmes that are currently active or were active until recently in the programme areas. A better understanding of other nutrition-related activities will help to determine whether potential changes in nutritional status can be attributed to the newly introduced nutrition interventions or not. 
Table 5.1: Key features and observed challenges of the nutrition interventions in the three livelihood programmes

\begin{tabular}{|c|c|c|c|}
\hline Features & Shiree Concern & CLP & UPPR \\
\hline Beneficiaries & $\begin{array}{l}\text { Pregnant women and } \\
\text { lactating mothers and their } \\
\text { children (up to } 5 \text { years and } \\
\text { adolescent girls) who } \\
\text { were/or still are } \\
\text { beneficiaries of the } \\
\text { livelihood programme }\end{array}$ & $\begin{array}{l}\text { Pregnant women and } \\
\text { lactating mothers and their } \\
\text { children (up to } 5 \text { years and } \\
\text { adolescent girls) who } \\
\text { were/or still are } \\
\text { beneficiaries of the } \\
\text { livelihood programme } \\
\text { Referral for malnourished } \\
\text { children up to } 5 \text { years }\end{array}$ & $\begin{array}{l}\text { Pregnant women and } \\
\text { lactating mothers and their } \\
\text { children (up to } 5 \text { years and } \\
\text { adolescent girls) } \\
\text { Newly selected and not } \\
\text { necessary beneficiaries of } \\
\text { the livelihood support }\end{array}$ \\
\hline $\begin{array}{l}\text { Features as } \\
\text { observed by } \\
\text { the qualitative } \\
\text { team }\end{array}$ & $\begin{array}{l}\text { Biweekly household-level } \\
\text { counselling for pregnant } \\
\text { and lactating mothers } \\
\text { (only) about Infant and } \\
\text { Young Child Feeding (IYCF) } \\
\text { and hygiene practices by } \\
\text { nutrition worker } \\
\text { Monthly community-level } \\
\text { counselling about child } \\
\text { nutrition and care } \\
\text { moderated by nutrition } \\
\text { worker for mothers and } \\
\text { adolescent girls } \\
\text { Iron folic acid tablets for } \\
\text { pregnant women after } 4 \\
\text { months of pregnancy until } \\
6 \text { months of breastfeeding } \\
\text { Monthly iron folic acid } \\
\text { tablets for adolescent girls } \\
5 \text { micronutrient powder for } \\
\text { children aged } 7 \text { to } 23 \\
\text { months (to start June } 2014 \text { ) }\end{array}$ & $\begin{array}{l}\text { Monthly household-level } \\
\text { counselling for pregnant } \\
\text { and lactating mothers } \\
\text { (only) about Infant and } \\
\text { Young Child Feeding (IYCF) } \\
\text { and hygiene practices by } \\
\text { nutrition worker } \\
\text { Some community-level } \\
\text { counselling (unclear how } \\
\text { frequently it is provided) }\end{array}$ & $\begin{array}{l}\text { Monthly household-level } \\
\text { counselling for pregnant } \\
\text { and lactating mothers } \\
\text { (only) about Infant and } \\
\text { Young Child Feeding (IYCF) } \\
\text { and hygiene practices by } \\
\text { nutrition worker } \\
\text { Once every three months } \\
\text { community-level } \\
\text { counselling about child } \\
\text { nutrition and care } \\
\text { moderated by nutrition } \\
\text { worker for mothers and } \\
\text { adolescent girls } \\
\text { Iron folic acid tablets for } \\
\text { pregnant women after } 4 \\
\text { months of pregnancy until } 6 \\
\text { months of breastfeeding } \\
\text { No iron_folic acid for } \\
\text { adolescent girls } \\
\text { Micronutrient powder for } \\
\text { children aged } 7 \text { to } 23 \\
\text { months (has not started at } \\
\text { the time of the qualitative } \\
\text { data collection) } \\
\text { Deworming for children } \\
\text { between } 6 \text { months and } 5 \\
\text { years, pregnant women } \\
\text { (after first trimester) and } \\
\text { adolescent girls every } 6 \\
\text { months }\end{array}$ \\
\hline
\end{tabular}




\begin{tabular}{|c|c|c|c|}
\hline & \multicolumn{3}{|c|}{$\begin{array}{l}\text { - Dietary recommendation provided by the nutrition workers were often perceived as } \\
\text { not context-specific enough and food recommended was often unavailable in the } \\
\text { location } \\
\text { - Nutrition community workers' capacity and knowledge about nutrition seem to vary } \\
\text { greatly } \\
\text { - Misconceptions about the impact of folic acid iron during pregnancy (e.g. baby gets } \\
\text { too big resulting in difficult labour or C-sections, baby will be very dark-skinned as iron } \\
\text { is dark, tablets interfere with the natural process of pregnancy and birth) } \\
\text { - Side effects of iron tablets (e.g. nausea, stomach pain, constipation, dizziness) led to } \\
\text { discontinuation of use among many mothers } \\
\text { - Recommendations of nutrition workers frequently contrasted with advice given by } \\
\text { local midwives and mothers-in-law Important to involve them as well as the wider } \\
\text { community in the intervention) } \\
\text { - Purchased micronutrients and irons tablet (e.g. BRAC health facility) are often more } \\
\text { highly valued than supplements provided free-of-charge } \\
\text { - Targeted households were often not reached by the micronutrient supplementations }\end{array}$} \\
\hline $\begin{array}{l}\text { Other nutrition } \\
\text { \& health } \\
\text { programmes } \\
\text { and } \\
\text { interventions }\end{array}$ & $\begin{array}{l}\text { BRAC health programme } \\
\text { (provides advice and } \\
\text { micronutrients/iron for } \\
\text { purchase) } \\
\text { NGO provides additional } \\
\text { food for pregnant women } \\
\text { until child birth } \\
\text { Government health } \\
\text { workers provide Vitamin A, } \\
\text { deworming to school-aged } \\
\text { children and vaccinations }\end{array}$ & $\begin{array}{l}\text { BRAC health programme } \\
\text { (provides advice and } \\
\text { micronutrients/iron for } \\
\text { purchase) } \\
\text { Small local NGOs provide } \\
\text { health advice }\end{array}$ & $\begin{array}{l}\text { BRAC health programme } \\
\text { (provides advice and } \\
\text { micronutrients/iron for } \\
\text { purchase) } \\
\text { Small local NGOs provide } \\
\text { low-cost healthcare }\end{array}$ \\
\hline
\end{tabular}




\section{CONCLUSIONS}

This section sets out some conclusions emerging from the combination of quantitative and qualitative baseline data that can inform the end line data collection and analysis of this evaluation. The qualitative findings are based on qualitative data collected from a sub-sample of the quantitative study sites in the 3 programme areas. The aim of the qualitative work was to gain an in-depth understanding of the context and processes within which the interventions are embedded and which might affect the success/failure of the intervention.

Child undernutrition was a major challenge across all three programme areas with the highest prevalence found in Shiree study communities and the lowest in UPPR study communities. Nevertheless it was not perceived as a priority by the local communities which might affect communities' motivation to take up the nutrition interventions.

With regards to child nutrition, overall breastfeeding practices were good with most infants being breastfed. However, the qualitative findings suggest that prelactael feeding was widely practiced and culturally supported often despite recommendations of health workers. As the majority of women deliver at home, facility-based discouragement of prelactael feeding does not reach most women. Home delivery may also influence opportunities of relatives to promote prelactael feeding. Continued prelactael feeding may interfere and reduce the effectiveness of breastfeeding promotion as part of the nutrition intervention.

Most mothers were aware of appropriate complementary feeding practices, but were unable to follow recommendations due to economic constraints, lack of time, limited availability and accessibility of fresh foods, limited knowledge of what constitutes age-appropriate food and cultural beliefs (constraints based on qualitative findings). Most of these factors will not be addressed by the nutrition intervention, but could be targeted (at least to some extent) by the livelihood intervention.

Maternal underweight was prevalent across all three programme areas and maternal diets were often poor due to economic, social and geographical constraints. The qualitative work suggests that food taboos and specific behaviours during pregnancy were common and encouraged by local community members. Some of these practices may be harmful to both mother and the unborn child and could interfere with the behaviour change messages provided by the intervention. Thus an understanding of local practices and adaptation of behaviour change messages to the specific local context might help to increase effectiveness.

Use of antenatal care was relatively high (especially in UPPR and CLP study communities), but delivery attended by a nurse, medically trained midwife or doctor was still low. According to the qualitative findings reasons for this were a lack of trust in medical facilities, misinformation and limited accessibility during rainy seasons. Mothers who deliver at home and with support of a traditional midwife only, may be at higher risk of morbidity and mortality (WHO 2006), both will affect the nutrition and care of the new-born.

Access to safe drinking water was almost universal across the three areas according to the quantitative findings. However, the qualitative findings highlighted that seasonal variations caused by flooding and droughts frequently restricted the use of safe water sources for long periods and forced households to rely on unsafe water sources. While many mothers (particularly in CLP study communities) were aware 
of strategies to treat water to reduce the risk of waterborne diseases (e.g. boiling, safe storage), lack of time and fuel often prevented these practices. The impact of regular deworming, micronutrient supplementation and behaviour change communication may be reduced considerably if waterborne diseases continue to be a health problem in the targeted communities.

Access to improved sanitation was low in Shiree study communities, but higher in CLP and UPPR. The common practice of shared sanitation facilities often led to dissatisfaction, conflict and eventually discontinuation of use. Low community-driven maintenance of latrines was another common challenge. Low usage and the lack of year-round reliable coverage of improved sanitation may hamper the effectiveness of the nutrition intervention through sanitation-related diseases (e.g. diarrhoea, worm infestation, and eye infections). Open defecation was still widely practiced especially during the rainy season when latrines were unusable due to overflow. While knowledge about good hygiene practices was relatively high, poor living environments, acute water shortage or flooding often prevented practice and may prevent effective up-take of behaviour change messages regarding improved hygiene.

Both Shiree and CLP study communities were highly vulnerable to climatic events (i.e. flooding, storms, droughts) that frequently led to loss of assets and worsening of child health and nutrition outcomes. UPPR study communities were annually affected by monsoons that resulted in flooding, worsening of child health and nutrition and loss of employment opportunities. Climatic events may (temporarily or seasonally) reduce the impact of the interventions. However, different measures as part the livelihood intervention aim to increase resilience and coping strategies and may thus reduce the negative consequences for beneficiary households.

With regards to intra-household decision-making about child health and nutrition, most mothers reported joint decision-making with their husbands with strong additional influence of mothers-in-law and elderly community members. The majority of mothers felt powerless and with little control over their lives both due to (1) extreme poverty and consequent lack of choices (e.g. child care, nutrition, education); AND (2) traditional roles and associated expectations they had to comply with (e.g. following advice of mother in law). The livelihood intervention and its benefits (e.g. access to income and loans) may raise women's social status and decision-making power in the household and community. However, behaviour change communication on child health and nutrition is likely to be only marginally effective if mothers-in-laws and husbands are not educated in parallel.

Baseline conditions also varied between study communities with Shiree and CLP slightly worse off with regards to child undernutrition and its underlying factors than UPPR. The three livelihood programmes varied greatly with regards to the beneficiary selection, services provided, delivery channels and beneficiary satisfaction with the programme.

Overall the baseline findings suggest that the new nutrition interventions may only achieve their full potential in improving child and maternal nutrition if they are combined with parallel improvements in the social, economic, cultural and environmental contexts of the beneficiaries, suggesting that interventions need to be context-specific. 


\section{REFERENCES}

Bamberger, M, Rugh, J, Mabry, L (2012). Real World evaluations. Thousand Oaks, CA:Sage.

Bhutta, ZA, et al. (2012). "Reducing maternal, newborn, and infant mortality globally: an integrated action agenda." International Journal of Gynecology \& Obstetrics; 119: S13-S17.

Black, RE, et al. (2013). "Maternal and child undernutrition and overweight in low-income and middle-income countries." The Lancet; 382(9890): 427-451.

Cairncross, S, et al. (2010). "Water, sanitation and hygiene for the prevention of diarrhoea." International journal of epidemiology; 39 (suppl 1): i193-i205.

Chambers, R, von Medeazza, G (2014). Reframing Undernutrition: Faecally-Transmitted Infections and the 5 As. IDS Working Paper 450, IDS:Brighton.

CLP (2014). Chars Livelihoods Programme-Our maps. Accessed $10^{\text {th }}$ January 2015: http://clp bangladesh.org/publications/our-maps/

Dangour, AD, et al. (2013). "Interventions to improve water quality and supply, sanitation and hygiene practices, and their effects on the nutritional status of children." Cochrane Database Syst Rev; 8.

DHS (2013). Demographic and Health Survey Bangladesh-2011. Calverton, Maryland, USA, National Institute of Population and Training, Mitra and Associates, Dhaka, Bangladesh and MEASURE DHS, ICF International.

Feldman, S (2011). "Exploring theories of patriarchy: A perspective from contemporary bangladesh." Signs; 26(4):1097-1097-1127.

Fewtrell, L, et al. (2005). "Water, sanitation, and hygiene interventions to reduce diarrhoea in less developed countries: a systematic review and meta-analysis." Lancet Infectious Diseases; 5(1): 42-52.

FU, A, et al. (1996). "Prelacteal feeding: influencing factors and relation to establishment of lactation." Bangladesh Med. Res. Counc. Bull; 22(2): 60-64.

Guba, E.G. and Lincoln Y.S. (1989). Fourth Generation Evaluation. Newbury Park, CA: Sage.

Haider R, Ashworth A, Kabir I, Huttly SRA (2000). "Effect of community based peer counsellors on exclusive breastfeeding practices in Dhaka, Bangladesh: a randomised controlled trial." Lancet; 356: 1643-47.

Helen Keller International (2001). "Complementary feeding in rural Bangladesh: Family foods for breast-fed infants.” Nutritional Surveillance Project Bulletin; 6:1-4.

Kimmons JE, Dewey KG, Haque E, Chakraborty J, Osendarp SJ, Brown KH (2005). "Low nutrient intakes among infants in rural Bangladesh are attributable to low intake and micronutrient density of complementary foods." J Nutr; 135:444-51.

Mihrshahi S, Oddy WH, Peat JK, Kabir I (2008). "Association between infant feeding patterns and diarrhoeal and respiratory illness: a cohort study in Chittagong, Bangladesh.” Int Breastfeed J; 3:28.

Moore AC, Akhter S, Aboud FE (2006). "Responsive complementary feeding in rural Bangladesh." Soc Sci Med; 62:1917-30.

Morse, JM (1995). “The significance of saturation.” Qualitative Health Research; 5, 147-149. 
Rasheed S, Frongillo EA, Devine CM, Alam DS, Rasmussen KM (2009). "Maternal, infant, and household factors are associated with breast-feeding trajectories during infants' first 6 mo of life in Matlab, Bangladesh.” J Nutr; 139:1582-7.

Nguyen, PH, et al. (2013). "Prelacteal feeding practices in Vietnam: challenges and associated factors." BMC public health; 13(1): 932.

Prüss, A, et al. (2002). "Estimating the burden of disease from water, sanitation, and hygiene at a global level." Environmental health perspectives; 110(5): 537-542.

Rahman, MM, et al. (2010). "The challenges of local environmental problems facing the urban poor in Chittagong, Bangladesh: a scale-sensitive analysis." Environment and Urbanization; 22(2): 561578.

Rajaratnam, JK, et al. (2010). "Neonatal, postneonatal, childhood, and under-5 mortality for 187 countries, 1970-2010: a systematic analysis of progress towards Millennium Development Goal 4." The Lancet; 375(9730): 1988-2008.

Sundaram, ME, et al. (2013). "Early neonatal feeding is common and associated with subsequent breastfeeding behavior in rural Bangladesh." The Journal of nutrition; 143(7): 1161-1167.

van Beukering, $\mathrm{M}$ et al. (2014). "Physically demanding work and preterm delivery: a systematic review and meta-analysis." International archives of occupational and environmental health; 1-26.

Walton, LM and Brown, D and Schbley, PhD (2012). "Bassima, Cultural Barriers to Maternal Health Care in Rural Bangladesh” Journal of Health Ethics; Fall 2012.

WHO (2006). "Making Pregnancy Safer: The critical role of the skilled attendant. A joint statement by WHO, ICM and FIGO." Genevea, World Health Organisation.

WHO (2006). "Neonatal and perinatal mortality: country, regional and global estimates." Genevea, World Health Organisation.

WHO (2014). "Classification for assessing severity of malnutrition by prevalence ranges among children under 5 years of age." Genevea, World Health Organisation. 


\section{APPENDIX A: MAP OF CLP SITE IN BANGLADESH}

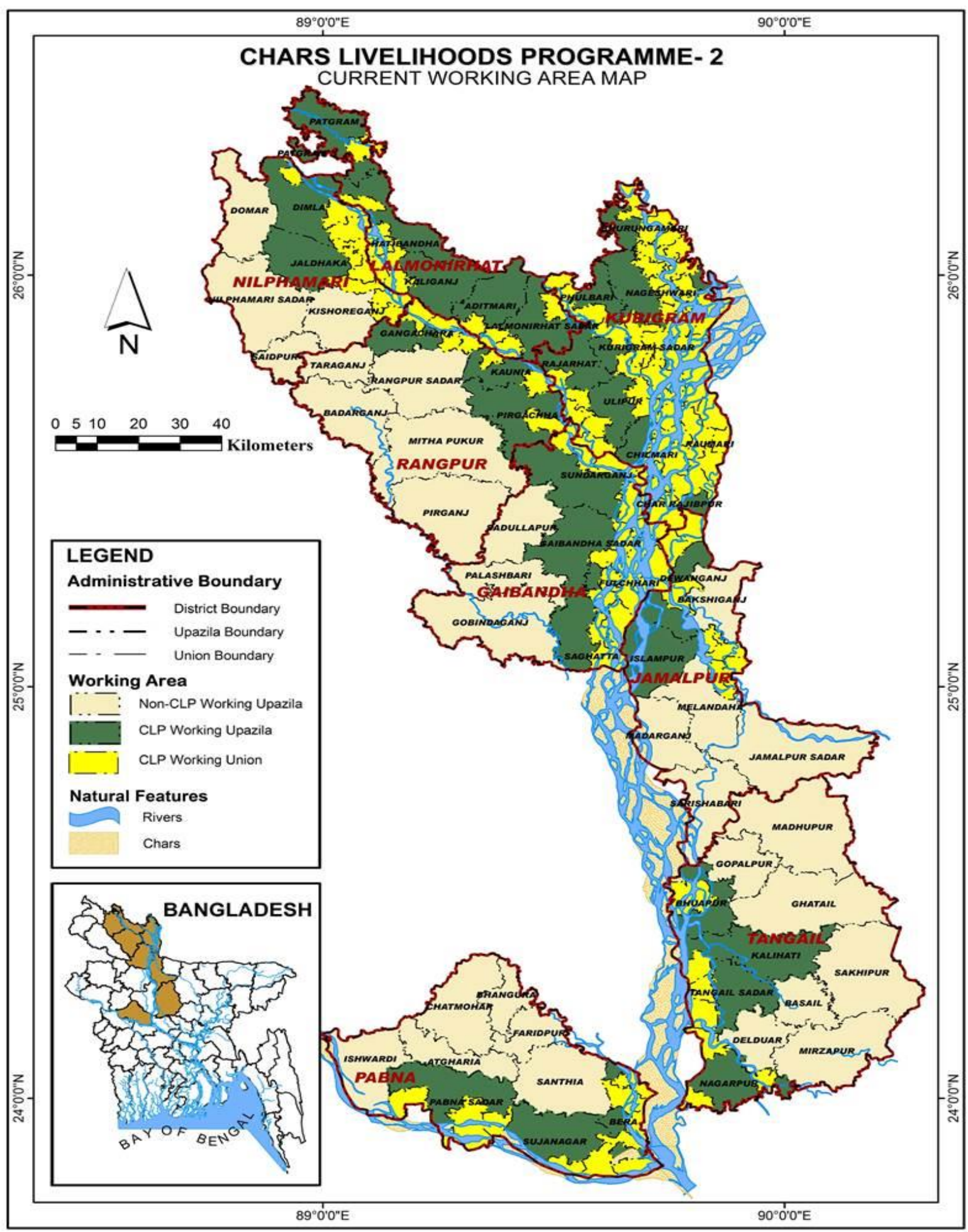




\section{APPENDIX B: MAP OF SHIREE/CONCERN SITES IN BANGLADESH}

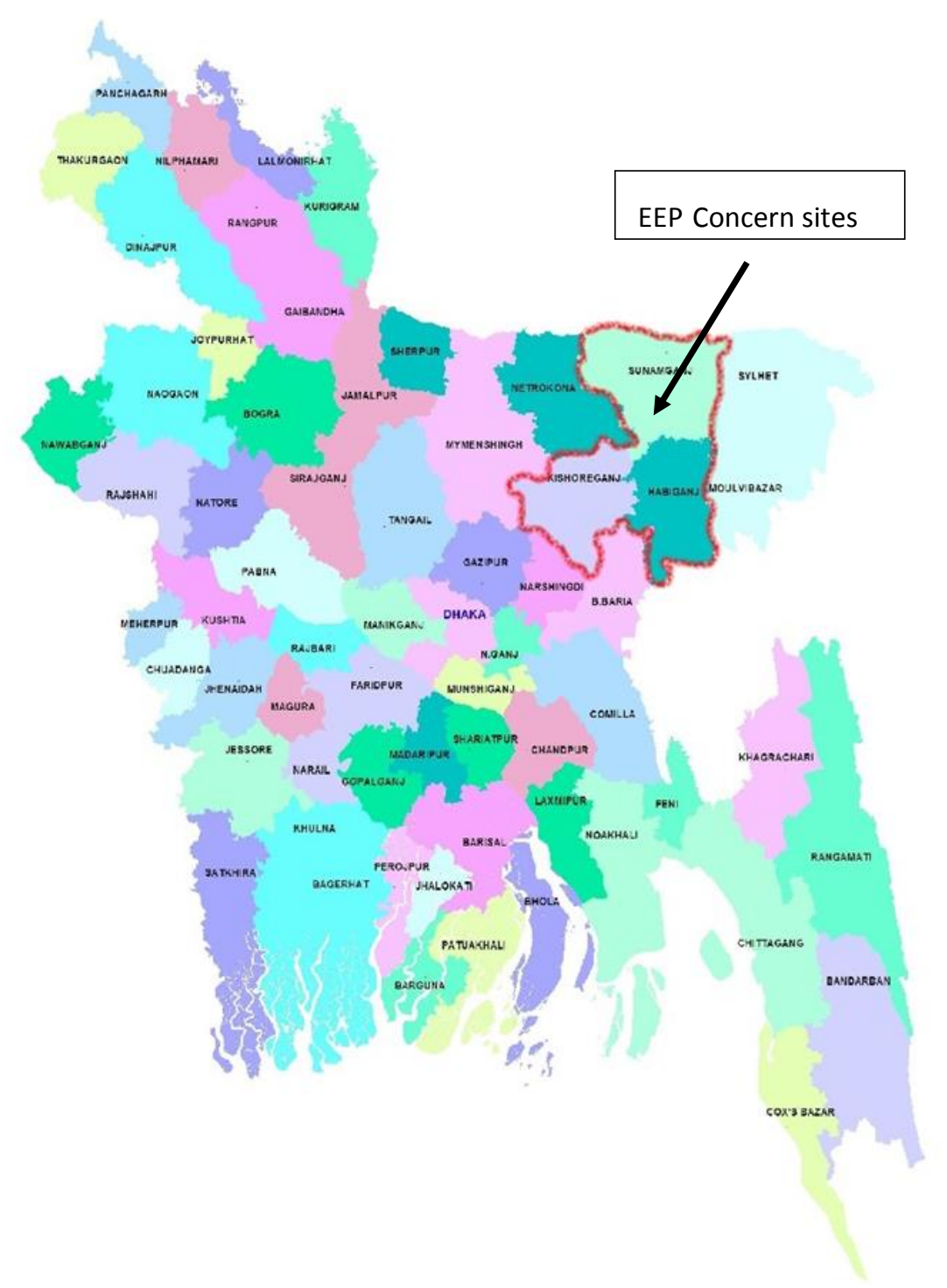

Source: SHIREE 2013 


\section{APPENDIX C: SUMMARY OF QUALITATIVE METHODS AND SAMPLES USED}

Table 1: Qualitative data collection methods used, stakeholders and purpose

\begin{tabular}{|c|c|c|}
\hline Methods & Stakeholder & Purpose \\
\hline $\begin{array}{l}\text { Social } \\
\text { Mapping }\end{array}$ & $\begin{array}{l}\text { - Leaders } \\
\text { - Key individual } \\
\text { - Male and female } \\
\text { community members with } \\
\text { different socioeconomic } \\
\text { backgrounds } \\
\end{array}$ & $\begin{array}{l}\text { To explore social networks, relationships and interactions in the } \\
\text { community }\end{array}$ \\
\hline $\begin{array}{l}\text { In-depth } \\
\text { interviews }\end{array}$ & $\begin{array}{l}\text { - Beneficiaries of L only } \\
\text { intervention } \\
\text { - Beneficiaries of } \mathrm{L}+\mathrm{N} \\
\text { intervention } \\
\text { - Non beneficiaries (female) } \\
\text { - Key Informants from the } \\
\text { communities }\end{array}$ & $\begin{array}{l}\text { To explore personal views, perceptions and judgements of the } \\
\text { interventions and influence on behaviour change } \\
\text { To explore existing nutritional behaviour patterns and resources and } \\
\text { in how far they might influence the success or failure of the } \\
\text { interventions } \\
\text { To understand the context of programmes and interventions and how } \\
\text { and why context can influence the interventions } \\
\text { To understand family structures and household decision-making } \\
\text { processes with regards to the interventions }\end{array}$ \\
\hline $\begin{array}{l}\text { Focus Group } \\
\text { Discussion }\end{array}$ & $\begin{array}{l}\text { - Beneficiaries of } \mathrm{L} \text { only } \\
\text { intervention } \\
\text { - Beneficiaries of } \mathrm{L}+\mathrm{N} \\
\text { intervention } \\
\text { - Non beneficiaries (female) }\end{array}$ & $\begin{array}{l}\text { To explore perceptions and experiences with the interventions } \\
\text { especially with regards to interactions within the community } \\
\text { To explore contextual factors and wider changes within the } \\
\text { communities } \\
\text { To explore effect of interventions on existing community structures }\end{array}$ \\
\hline $\begin{array}{l}\text { Participatory } \\
\text { observation }\end{array}$ & $\begin{array}{l}\text { Livelihood beneficiary } \\
\text { HH with children 6-24 } \\
\text { months } \\
\text { - Livelihood and nutrition } \\
\text { beneficiary HH with } \\
\text { children 6-24 months } \\
\text { - Non beneficiary HH with } \\
\text { children 6-24 months }\end{array}$ & $\begin{array}{l}\text { To explore beneficiaries' experiences and perceptions of the } \\
\text { programmes and the different interventions } \\
\text { To understand family structures and household decision-making } \\
\text { processes with regards to the interventions } \\
\text { To explore existing nutritional behaviour patterns and resources and } \\
\text { in how far they might influence the success or failure of the } \\
\text { interventions }\end{array}$ \\
\hline Life history & $\begin{array}{l}\text { - Livelihood beneficiary } \\
\text { HH with children 6-24 } \\
\text { months } \\
\text { - Livelihood and Nutrition } \\
\text { beneficiary HH with } \\
\text { children 6-24 months } \\
\text { - Non beneficiary HH with } \\
\text { children 6-24 months }\end{array}$ & $\begin{array}{l}\text { To understand the beneficiaries' experiences and perceptions of the } \\
\text { programmes within a personal historical, social and economic } \\
\text { context and characteristics } \\
\text { To identify barriers and facilitators of intervention up-take uptake }\end{array}$ \\
\hline
\end{tabular}


Table 2: Qualitative samples for the different data collection methods in CLP, SHIREE and UPPRP

\begin{tabular}{|c|c|c|c|c|c|c|c|}
\hline & Methods & $\begin{array}{c}\text { Stakeholder/Respondent } \\
\text { group }\end{array}$ & $\begin{array}{c}\text { L+N } \\
\text { AREA }\end{array}$ & $\begin{array}{l}\text { L ONLY } \\
\text { AREA }\end{array}$ & $\begin{array}{l}\text { CONTRO } \\
\text { L AREA }\end{array}$ & $\begin{array}{l}\text { Number of } \\
\text { activities } \\
\text { (Each } \\
\text { programme) }\end{array}$ & $\begin{array}{l}\text { Total } \\
\text { units }\end{array}$ \\
\hline 1 & $\begin{array}{l}\text { Social } \\
\text { Mapping }\end{array}$ & $\begin{array}{l}\text { - Local elite, key } \\
\text { individual, people from } \\
\text { different occupational } \\
\text { groups } \\
\end{array}$ & 1 & 1 & 1 & 3 & 9 \\
\hline \multirow[t]{5}{*}{2} & \multirow{5}{*}{$\begin{array}{l}\text { In-depth } \\
\text { interviews }\end{array}$} & - Local elite (3) & 1 & 1 & 1 & \multirow{5}{*}{18} & \multirow{5}{*}{54} \\
\hline & & - Partner NGO official (2) & $\begin{array}{c}1(\mathrm{~N} \\
\text { official) }\end{array}$ & $\begin{array}{c}1(\mathrm{~L} \\
\text { official })\end{array}$ & & & \\
\hline & & $\begin{array}{l}\text { - Health worker/nutrition } \\
\text { worker (4) }\end{array}$ & $\begin{array}{l}2 \text { (Health } \\
\text { and } \\
\text { nutrition } \\
\text { worker) }\end{array}$ & $\begin{array}{l}1 \text { (health } \\
\text { worker) }\end{array}$ & $\begin{array}{l}1 \text { (other org } \\
\text { health } \\
\text { worker) }\end{array}$ & & \\
\hline & & $\begin{array}{l}\text { - Elderly Male HH member } \\
\text { (3) }\end{array}$ & 1 & 1 & 1 & & \\
\hline & & $\begin{array}{l}\text { Elderly female } \mathrm{HH} \\
\text { member (6) }\end{array}$ & 2 & 2 & 2 & & \\
\hline \multirow[t]{4}{*}{3} & \multirow[t]{4}{*}{$\begin{array}{l}\text { Focus Group } \\
\text { Discussion }\end{array}$} & $\begin{array}{l}\text { - beneficiaries of L only } \\
\text { intervention (2) }\end{array}$ & & 2 & & \multirow{4}{*}{9} & \multirow{4}{*}{27} \\
\hline & & $\begin{array}{l}\text { Beneficiaries of } \mathrm{L}+\mathrm{N} \\
\text { intervention (2) }\end{array}$ & 2 & & & & \\
\hline & & $\begin{array}{l}\text { - non beneficiaries (female) } \\
\text { (2) }\end{array}$ & & & 2 & & \\
\hline & & $\begin{array}{l}\text { Male from different } \\
\text { occupation group (3) }\end{array}$ & 1 & 1 & 1 & & \\
\hline \multirow[t]{3}{*}{4} & \multirow[t]{3}{*}{$\begin{array}{l}\text { Household } \\
\text { level } \\
\text { Observation }\end{array}$} & $\begin{array}{l}\text { - Livelihood Beneficiaries } \\
\text { HH of 6-24 months } \\
\text { children (2) }\end{array}$ & & 2 & & \multirow{3}{*}{6} & \multirow{3}{*}{18} \\
\hline & & $\begin{array}{l}\text { Livelihood and nutrition } \\
\text { beneficiary's HH of 6-24 } \\
\text { months children (2) }\end{array}$ & 2 & & & & \\
\hline & & $\begin{array}{l}\text { Non beneficiary's HH of } \\
\text { 6-24 months children (2) }\end{array}$ & & & 2 & & \\
\hline \multirow[t]{4}{*}{5} & \multirow[t]{3}{*}{ Life history } & $\begin{array}{l}\text { Livelihood Beneficiaries } \\
\text { HH of 6-24 months } \\
\text { children (3) }\end{array}$ & & 3 & & \multirow{3}{*}{9} & \multirow{3}{*}{27} \\
\hline & & $\begin{array}{l}\text { Livelihood and nutrition } \\
\text { beneficiary's HH of 6-24 } \\
\text { months children (3) }\end{array}$ & 3 & & & & \\
\hline & & $\begin{array}{l}\text { Non beneficiary's HH of } \\
\text { 6-24 months children (3) }\end{array}$ & & & 3 & & \\
\hline & & Total & & & & 45 & 135 \\
\hline
\end{tabular}




\title{
APPENDIX D: MIXED METHOD WORKSHOP AGENDA
}

\author{
Impact evaluation of DFID's Nutrition \& Livelihood interventions in Bangladesh
}

Monday-Tuesday $23^{\text {rd }}-24^{\text {th }}$ June 2014, Dhaka

\section{Objectives}

The aim of this 2-day workshop is to integrate quantitative and qualitative baseline findings to gain in-depth insights into the contexts in which the $\mathrm{L}$ and $\mathrm{N}$ interventions are embedded within CLP, Shiree and UPPR programmes. This will help us to identify economic, political, social and cultural factors that potentially may influence/hinder up-take of the livelihood and nutrition interventions and behaviour change and potentially shape the design of remaining quantitative and qualitative fieldwork activities.

By combining quantitative and qualitative findings, the workshop aims to address the following objectives:

\section{Examine child undernutrition and underlying reasons across the sites in the 3 programmes}

This will include findings on the manifestation of child undernutrition in the different sites, the disconnect between nutritional knowledge and actual practices, economic \& cultural factors responsible for disconnect, nutrition-related decision making and attitude of other household members to child care and feeding, household food security, past nutrition interventions and perceived benefits, etc.)

2. Assess the features of the existing livelihood intervention, its benefits and challenges across the 3 programmes

This will including descriptions of the key features (i.e. services, assets) of the interventions, beneficiaries experiences, challenges and perceptions, benefits and challenges of saving group, potential reasons for why the livelihood intervention has not resulted in an improvement of nutrition, sustainability of benefits from livelihood programme (e.g. what happens to the assets, what challenges do household face), access and utilisation of other livelihood services, unintended consequences, etc.)

3. Explore the living environments and social, economic, cultural contexts across the sites in the 3 programmes

This will include environmental factors that may influence child nutrition outcomes and up-take and effectiveness of the interventions such as access and utilisation of basic services (i.e. antenatal care, health, social), status of child health, WASH, dwelling conditions, social programming and benefits, challenges and overlaps, access to markets, political economy and power-relationships, women empowerment, vulnerability to shocks, etc.) 
Each session in the workshop will begin with a brief presentation of the quantitative and qualitative key findings to introduce common topics. This will be followed by a detailed discussion in two small groups. Each group will comprise quantitative and qualitative researchers who will plan how they would combine the quantitative and qualitative findings in writing. Groups will present findings to each other at the end of each session. The groups may also identify instances when further analysis of the raw data to follow up threads may offer new insights. If possible sessions will be concluded with an integrative synthesis matrix that will juxtapose quantitative and qualitative key findings and (potentially) speculate about effects on the up-take and impact of the $\mathrm{L}+\mathrm{N}$ intervention.

Quantitative and qualitative data collection has been conducted in a sequential manner. Quantitative data collection was completed before the start of the nutrition intervention, whereas qualitative data were collected after the nutrition intervention had commenced. Consequently, the qualitative data can provide first insights into the procedures, perceived benefits and attitudes towards the nutrition intervention and its micro-dynamics. The qualitative team will share these findings during the workshop and thus inform the development of the tools for the process evaluation that is due to start in July.

The key findings from the workshop will be written up and presented in a report which will be shared with DFID and programme partners in August/September 2014.

When? $23^{\text {rd }}$ and $24^{\text {th }}$ June 2014.

Where? International Food Policy Research Institute, House 10A, Road 35, Gulshan 2 Dhaka 1212, Phone: +88.02 .989 .8686$

Participants: to facilitate discussions and exchange of ideas the workshop will be kept small, and small sub-groups will be formed for more-in-depth explorations

Moderator: Ferdous Jahan

Note taker: BRAC-U will provide someone 


\section{Workshop Overview}

\begin{tabular}{|c|c|}
\hline \multicolumn{2}{|c|}{ Day 1 (participants are invited for lunch at noon at IFPRI) } \\
\hline $13 \mathrm{~h} 00$ & Introductions, aims and planned outcome of the workshop \\
\hline $13 \mathrm{~h} 30$ & $\begin{array}{l}\text { Brief descriptions of the quantitative data collection and its challenges (including } \\
\text { implementation challenges) }\end{array}$ \\
\hline $14 \mathrm{~h} 00$ & Brief description of the qualitative data collection and its challenges \\
\hline $14 \mathrm{~h} 30$ & $\begin{array}{l}\text { Child undernutrition and underlying reasons across the study sites in the three } \\
\text { programmes } \\
\text { - Quantitative presentation (15 minutes) } \\
\text { - Qualitative presentation (15 minutes) } \\
\text { - Group work on emerging themes based on quantitative and qualitative } \\
\text { findings and preparing the writing plan (bullet points/skeleton) (30 minutes) }\end{array}$ \\
\hline $15 \mathrm{~h} 30$ & Tea/coffee break \\
\hline $16 \mathrm{~h} 00$ & $\begin{array}{l}\text { - } \text { Group presentations on undernutrition findings (20 minutes) } \\
\text { - } \quad \text { Discussion on summary of key findings (40 min) }\end{array}$ \\
\hline $17 \mathrm{~h} 00$ & $\begin{array}{l}\text { The existing livelihood intervention, its features, challenges across study sites in the } \\
\text { three programmes } \\
\text { - Quantitative presentation (15 minutes) } \\
\text { - Qualitative presentation (15 minutes) } \\
\text { - Group work on emerging themes based on quantitative and qualitative } \\
\text { findings and preparing the writing plan (bullet points/skeleton) (30 minutes) }\end{array}$ \\
\hline $18 \mathrm{~h} 00$ & Close \\
\hline
\end{tabular}

\begin{tabular}{|c|c|}
\hline Day 2 & \\
\hline $08 \mathrm{~h} 30$ & $\begin{array}{l}\text { - Group presentations on livelihood findings (20 minutes) } \\
\text { - } \quad \text { Discussion on summary of key findings (40 min) }\end{array}$ \\
\hline 09h30 & $\begin{array}{l}\text { Summary of key findings from the integration of quantitative and qualitative evidence } \\
\text { on day } 1 \\
\text { Aims of day } 2\end{array}$ \\
\hline $10 \mathrm{~h} 30$ & $\begin{array}{l}\text { The living environment and the contexts of the study sites Including other social } \\
\text { programmes and nutrition interventions } \\
\text { - Quantitative presentation ( } 30 \text { minutes) } \\
\text { - Qualitative presentation (30 minutes) }\end{array}$ \\
\hline $11 \mathrm{~h} 30$ & Coffee/ tea break \\
\hline $12 \mathrm{~h} 00$ & $\begin{array}{l}\text { - Group work on emerging themes based on quantitative and qualitative } \\
\text { findings and preparing the writing plan (bullet points/skeleton) (60 minutes) }\end{array}$ \\
\hline $13 \mathrm{~h} 00$ & Lunch \\
\hline $14 \mathrm{~h} 00$ & - Group presentations on contextual findings (30 minutes) \\
\hline
\end{tabular}




\begin{tabular}{|c|c|}
\hline & - Discussion on summary of key findings (30 min) \\
\hline $15 \mathrm{~h} 00$ & $\begin{array}{l}\text { The micro-dynamics of the nutrition interventions, observed benefits, challenges, } \\
\text { unintended consequences observed modifications by implementers } \\
\text { - Presentation by the qualitative team (15 min) } \\
\text { - Discussion (30 min) }\end{array}$ \\
\hline $15 \mathrm{~h} 30$ & $\begin{array}{l}\text { Process evaluation methodology and plans for contributions to qualitative and } \\
\text { quantitative data }\end{array}$ \\
\hline $16 \mathrm{~h} 00$ & Coffee / tea break \\
\hline $16 h 30$ & $\begin{array}{l}\text { Quant evaluation design vs. actual implementation (challenges and how we can address } \\
\text { them) }\end{array}$ \\
\hline $17 \mathrm{~h} 00$ & $\begin{array}{l}\text { Discussion of potential other themes and next steps (e.g. further disaggregated } \\
\text { analysis) } \\
\text { - Organisation of outcome report from the workshop } \\
\text { - Further development of the ToC based on the workshop findings } \\
\text { - Further analysis to unpack specific aspects of the evaluation further (e.g. realist } \\
\text { evaluation, in-depth case study analysis combining quant and qual data at village- } \\
\text { level) }\end{array}$ \\
\hline $18 \mathrm{~h} 00$ & Close \\
\hline
\end{tabular}




\section{APPENDIX E: LIST OF WORKSHOP PARTICIPANTS}

- Inka Barnett (IDS, co-moderating the workshop)

- Ferdous Jahan (BRAC-U, co-moderating the workshop)

- Faruque Sidikki (BRAC-U)

- Shalini Roy (IFPRI)

- Firdousi Naher (IFPRI)

- Anis Islam (CNRS)

- Firoj Ahmed (CNRS)

- Nick Nisbett (IDS)

- Alex Cornelius (ITAD)

- Richard Longhurst (IDS)

- Jessica Gordon (IDS) 